REVISTA DE DERECho UNED, NÚM. 7, 2010

\title{
LA PROTECCIÓN JURÍDICO-PATRIMONIAL DEL MENOR Y DEL INCAPACITADO Y SU ANTECEDENTE HISTÓRICO EN DERECHO ROMANO*
}

\section{M $^{\mathrm{a}}$ DEL CARMEN CAZORLA GONZÁLEZ-SERRANO}

Profesora Ayudante. Universidad Rey Juan Carlos de Madrid.

Resumen: El presente artículo versa sobre las distintas formas de protección del menor y del incapacitado desde tiempos romanos hasta nuestros días.

Nuestro interés no es otro que llevar a cabo un profundo estudio de las instituciones de guarda, con especial atención a la institución tutelar orientada a la atención de las necesidades de aquellas personas que, por encontrarse en situación de especial vulnerabilidad, requieren un mayor apoyo para desarrollar las actividades esenciales de la vida diaria, alcanzar una mayor autonomía personal y poder ejercer plenamente sus derechos de ciudadanía.

Palabras Clave: Protección jurídico-patrimonial, paterfamilias, menor, incapacitado, tutela, curatela, defensor judicial, Consejo de familia, protutor.

Abstract: The present article focuses on the different types of protection of the minor and the disabled, from the times of the Romans to our days. Our main interest is to analyse in depth the foster care institutions, with special attention to those oriented to the assistance of the necessities of the people who, for the reason of being in a situ-

" El presente estudio se realiza en el marco del Proyecto de Investigación «La jurisdicción Voluntaria: un mandato legislativo pendiente de cumplimiento", financiado por el Ministerio de Ciencia e Innovación. DER2008 - 06460 - CO2-01, del que la Autora forma parte y el Profesor Antonio Fernández de Buján es el Investigador Principal. 
ation of special vulnerability, require more support in order for them to develop the essential everyday activities, to reach more personal independence and to fully exercise their rights as citizens.

Key Words: Juridical-Patrimonial Security, Pater Familiae (Pater Familias), minor, disabled, guardianship, conservatorship, court representative, Family council/board, pro-guardian.

Sumario: 1. Consideraciones preliminares. 2. Protección y asistencia del menor y del incapacitado en Roma. 3. Regulación de la institución tutelar en los distintos textos legislativos civiles. A) Proyecto de Código Civil de 1821. B) Proyecto de Código civil de 1836. C) Proyecto de Código civil de 1851. D) La Ley de Enjuiciamiento Civil de 3 de febrero de 1881. E) La regulación inicial del Código civil de 1889. F) Reformas introducidas por la Ley de 24 de abril de 1958. G) La Ley 13/1983, de 24 de octubre, de reforma del Código civil en materia de tutela. H) La Ley 41/2003, de 18 de noviembre, de Protección Patrimonial de las personas con discapacidad y de modificación del Código Civil, de la Ley de Enjuiciamiento Civil y de la normativa tributaria con esta finalidad. 4. Conclusiones.

\section{CONSIDERACIONES PRELIMINARES.}

Probablemente a muchos de nosotros se nos ha planteado alguna vez el dilema de decidir cuál es la mejor forma de actuar cuando vemos a un sujeto que por sus especiales circunstancias de vulnerabilidad necesita de algún organismo que le ampare y vele por sus intereses. Por ello, desde el punto de vista del Derecho de la persona, es preciso organizar una adecuada protección jurídica para los casos en que los menores e incapacitados no son atendidos por quienes están legalmente llamados a otorgarles protección, ya sean los padres o los tutores.

La institución familiar constituye el grupo humano que mayores garantías de óptimo desarrollo ofrece a los menores e incapacitados. Existen individuos, que por diversas razones no se encuentran sujetos a la patria potestad y no son capaces de regirse por sí mismos, necesitando el cuidado y atención de una persona que les asista. Por tanto, cuando falta la protección de los padres, la ley establece figuras supletorias de protección encaminadas a salvaguardar los intereses de los más débiles.

El derecho histórico nos revela una institución tutelar determinada por las bases arcaicas del derecho de familia. La tutela consti- 
LA PROTECCIÓN JURÍDICO-PATRIMONIAL DEL MENOR Y DEL INCAPACITADO ...

tuía una institución de protección que venía encuadrada dentro de los poderes que ostentaba el paterfamilias respecto de los sujetos que no estando bajo la patria potestas, no podían defenderse por sí mismos. Frente a las diferentes tutelas surgidas en Roma (en base a la situación que se encontraba el sujeto una vez muerto el paterfamilias), en nuestro derecho actual no se habla de diferentes tutelas pero sí de dos sistemas a través de los cuales ha podido organizarse la función tutelar, esto es, el sistema de tutela de familia, ya derogado, y el sistema de tutela de autoridad ${ }^{1}$.

Frente a la tutela, han ido surgiendo a lo largo de la historia distintas figuras destinadas al amparo y protección del menor y del incapacitado, que si bien haremos una breve alusión a las mismas, no constituirán objeto de profundo estudio en este trabajo.

En definitiva, nuestro interés no es otro que el análisis de las instituciones de protección, centrándonos de un modo especial en la institución tutelar. Con ella se persigue la protección, asistencia, cuidado y educación de los menores no emancipados e incapacitados no sujetos a la patria potestad, ostentando el tutor su representación en todos aquellos casos que no puedan actuar por sí solos ${ }^{2}$. El tutor puede, por tanto, como establece el artículo 267 del Código civil, representar o sustituir al pupilo no sólo en la esfera propiamente personal, sino también en la esfera patrimonial ${ }^{3}$.

${ }^{1}$ SANZ MARTÍN, L.: La tutela del Código Civil y su antecedente histórico la tutela romana, Dykinson, Madrid, 1998, p. 9.

${ }^{2}$ Vide, entre otros, CASTÁN TOBEÑAS, J.: Derecho Civil Español, Común y Foral, Derecho de Familia, t. V., $9^{a}$ ed., Reus, Madrid, 1985, p. 422; GARCÍA GARRIDO, M. J.: Derecho Privado Romano, $7^{\text {a }}$ ed., Dykinson, Madrid, 1997, pp. 242 y ss.; BERCOVITZ RODRIGUEZ-CANO, R.: Comentarios al Código Civil, Aranzadi, Navarra, 2001, pp. 337 y ss.; ALBALADEJO, M.: Curso de Derecho Civil IV, Derecho de Familia, $11^{\text {a }}$ ed., Edisofer, Madrid, 2008, p. 301.

La bibliografía de la tutela en Roma es profusa en estudios de carácter general y sobre aspectos específicos. Una síntesis al respecto puede contemplarse en los siguientes: SACHERS, en PW., suppl. VII, pp. 1947 y ss.; BEAUCHET y COLLINET, en DIS., V, pp. 553 y ss.; SOLAZZI (S.), en N.D.I., XII, 2, pp. 577 y ss.; ZANNINI (P.L.), en ED., 45, pp. 305 y ss.; TORRENT, A.: Diccionario de Derecho Romano, Edisofer, Madrid, 2005, pp. 1397-1399; y GARCÍA GARRIDO, M.J.: Diccionario de Jurisprudencia Romana, Dykinson, Madrid, 1982, pp. 345 y ss.

${ }^{3}$ Art. 267 C.c.: «El tutor es el representante del menor o incapacitado, salvo para aquellos actos que pueda realizar por sí solo, ya sea por disposición expresa de la Ley o de la sentencia de incapacitación». 


\section{PROTECCIÓN Y ASISTENCIA DEL MENOR Y DEL INCAPACITADO EN ROMA.}

En el seno del Derecho romano privado se configuraron desde sus orígenes una serie de instituciones tendentes a suplir la falta de capacidad de la que adolecían algunas personas.

Sin embargo, para abordar el tema de la protección jurídico-patrimonial del sujeto desamparado en Roma, es ciertamente necesario trazar un somero repaso a la institución familiar en esta época.

La familia romana se nos presenta como un conjunto de personas que vivían en comunidad en la casa familiar bajo la autoridad de quien ostentaba la patria potestad. A la cabeza se encontraba la persona del paterfamilias a la que se reconoció una amplia esfera de autonomía dentro del marco del Estado. El paterfamilias era el jefe del grupo familiar; sin embargo cabe apuntar que una persona es también paterfamilias, aunque no tenga hijos, ni familia bajo su potestad, siempre que no esté sometido a potestad ajena, dado que como subraya Ulpiano en D. 50. 16. 195. 2: "...se llama cabeza de familia al que tiene el dominio en la casa, y se le llama así, en sentido técnico, aunque no tenga hijos, dado que el término no sólo hace referencia a una relación personal, sino también a una posición jurídica, y así podemos también llamar cabeza de familia al pupilo...».

En relación con el carácter absoluto de la potestad paterna en los tiempos primitivos, éste evolucionó a través de graves restricciones en los poderes e imposición de ciertas obligaciones. La patria potestad se empieza a concebir como un officium, es decir, básicamente, como un deber de protección y asistencia.

Muerto el paterfamilias o extinguida de cualquier otra forma la patria potestad del pater, se nombraba un tutor. A la persona o personas designadas como tutores se le atribuye la función de suplir la capacidad del menor, si éste no ha superado la edad de la infancia, o de integrar o complementar dicha capacidad, si el menor ha sobrepasado la edad de 7 años, pero continúa siendo un impúber, al no haber alcanzado todavía la pubertad ${ }^{4}$.

${ }^{4}$ Véanse, SOLAZZI, S.: La Legge delle XII T. Sulla tutella e un'ipotesi del Bonfante, Scritti 3, 1960, p. 219; LEVY-BRÜHL, L.: La tutelle des XII Tables, studi in onore Solazzi, Nápoles, 1948, pp. 318 y ss; y FERNÁNDEZ DE BUJÁN, A.: Derecho Privado Romano, $3^{\mathrm{a}}$ ed., Iustel, 2010, p. 212. 
LA PROTECCIÓN JURÍDICO-PATRIMONIAL DEL MENOR Y DEL INCAPACITADO ...

En Derecho romano nos encontramos, pues, con dos institutos que cumplen la función de guarda y protección del menor o incapacitado, así, la tutela y la curatela.

La más célebre definición de la tutela se atribuye a SERVIO SULPICIO RUFO, que se refiere a ella como: «Un poder y una potestad sobre una persona libre que permite y otorga el derecho civil, para proteger a quien por razón de edad no puede defenderse por sí mismo» ${ }^{5}$.

En un primer momento, la tutela se configuró en Roma como un poder o potestas encomendado por la ley al heredero varón más próximo (proximus agnatus) ${ }^{6}$. Dicho poder lo ostentaba el paterfamilias quien gozaba de plena potestad sobre los impúberes y las mujeres ${ }^{7}$. El poder del tutor o paterfamilias era tal que a su muerte la familia no se disgregaba, sino que se mantenía unida, pasando la potestas a la persona por él designada. Las facultades o poderes del tutor eran, en un principio, de gran amplitud puesto que hacía y recibía pagos, invertía a su antojo los capitales, e incluso podía pignorar y enajenar los bienes del pupilo; en definitiva, se comportaba como si fuese el dueño del patrimonio pupilar ${ }^{8}$.

Por tanto, la esencia del cargo consistía en integrar la capacidad del pupilo, cuya voluntad, sin estar totalmente ausente, se completaba con la del tutor mediante la auctoritas interpositio. Es decir, dicha auctoritas presuponía un complemento de los actos realizados por el pupilo que servía como cooperación a la capacidad del sujeto, dando validez jurídica al acto ${ }^{9}$. Por ello, resultaba indispensable

${ }^{5}$ D. 26,1,1: «Tutela est vis ac potestas in capite libero ad tuendum eum qui propter eaetatem sua sponte se defendere nequit, iure civili data ac permissa».

${ }^{6}$ D. 26, 1, 16: "Tutela plerunque virile officium est» (La tutela es más veces oficio de varón). En el mismo sentido, se pronuncian, BONFANTE, P. (Corso di Diritto Romano, Diritto di Famiglia, vol. I, Giuffrè, Milano, 1963, p. 553) al señalar que «este carácter potestativo y egoísta está muy marcado en el modelo más arcaico, la tutela de las mujeres»; y GARCÍA GARRIDO, M. J.: Derecho Privado Romano..., cit., pp. 243 y ss. Por su parte, IGLESIAS REDONDO, J. (Derecho Romano, 12 $2^{\mathrm{a}}$ ed., Ariel, Barcelona, 1999, p. 357) sostiene que «tutor es, en primer término, el heres designado en testamento, y, a falta de designación, o existiendo sólo impúberes o mujeres, asume la tutela el proximus agnatus».

${ }^{7}$ Esta situación de sumisión absoluta de la mujer al paterfamilias la pone de manifiesto FERNÁNDEZ DE BUJÁN, F. (ob. cit., p. 47) al señalar que el paterfamilias, «además de dar tutor a los hijos impúberes, puede nombrar tutor para las mujeres sometidas a su potestad...».

${ }^{8}$ Vide ARIAS RAMOS, J.: Derecho Romano II, $3^{\mathrm{a}}$ ed., ed. Revista de Derecho Privado, Madrid, 1974, p. 747.

${ }^{9}$ Véanse, entre otros, BONFANTE, P.: ob. cit., p. 554; FUENTESECA, P.: Derecho Privado Romano, E. Sánchez A., Madrid, 1978, p. 408; BURDESE, A.: Manuale di Di- 
que el tutor estuviera presente en el momento de prestar su auxilio; el menor, en cierto modo, celebraba por sí mismo el acto jurídico de que se tratase gracias al consentimiento que el tutor inmediatamente otorgaba.

Sin embargo, en ocasiones, además de la auctoritas interpositio, el tutor ostentaba el negotiorum gestio o derecho de administrar el patrimonio del incapaz, en cuyo caso no se limitaba a asistir al pupilo, sino que, lo sustituía en los actos concernientes a sus bienes, actuando bajo su exclusiva responsabilidad ${ }^{10}$. En tales casos, el tutor realizaba y concluía los negocios del pupilo como si se tratase de negocios propios, de manera que ante el Ius Civile adquiría derechos y asumía obligaciones, convirtiéndose personalmente en propietario, acreedor y deudor. En cambio, las atenciones materiales de alimentación y educación del pupilo no formaban parte de las actividades del tutor, correspondiendo a la madre el cuidado y asistencia del incapaz en los restantes ámbitos en que requería ${ }^{11}$.

La institución tutelar puede distinguir en este periodo histórico dos modalidades de interés, así, la tutela impuberum y la tutela mulieris. El origen de estas dos clases de tutela radica, con carácter general, en las convicciones, necesidades y creencias del pueblo romano, y en particular en la propia organización familiar en donde se manifestaron. Una construcción de la tutela fuera del ámbito familiar resultaría impensable, ya que la fuerza del grupo familiar en la época primitiva, derivada de la estrecha unión de sus componentes, permitía que, ante una situación de peligro de cualquiera de sus miembros, la colectividad familiar respondiera, ofreciendo la ayuda necesaria $^{12}$.

La tutela impuberum o tutela del impúber comprendía la guarda de la persona, la administración de su patrimonio y la intervención en los

ritto Privato Romano, $4^{\text {a }}$ ed., Utet, Torino, 2000, p. 274; GARCÍA GARRIDO, M.J.: Derecho Privado Romano. Casos. Acciones. Instituciones, $16^{\mathrm{a}}$ ed. revisada, ediciones académicas, Madrid, 2008, p. 372; y SIERRA POMARES, D.M.: Voz «Tutela» en EJE, ed. Seix, t. trigésimo, Barcelona, pp. 470 y 471.

${ }^{10}$ En este sentido, CENDON, P.: Il Diritto Privato nella Giurisprudenza, La famiglia, Utet, Torino, 2000, p. 183; SIERRA POMARES, D.M.: ob. cit., pp. 470 y 471; y GARCÍA GARRIDO, J.M.: Derecho Privado Romano. Casos. Acciones. Instituciones..., cit., p. 372.

${ }^{11}$ Coinciden con este punto de vista, ARIAS RAMOS, J.: ob. cit., p. 746; y FUENTESECA, P.: ob. cit., p. 408.

12 Vide CASADO CANDELAS, M.J.: La tutela de la mujer en Roma, Universidad de Valladolid, Valladolid, 1972, p. 9. 
actos jurídicos que el incapacitado no podía realizar por sí sólo ${ }^{13}$. Así bien, la función del tutor se centraba en complementar la deficiente capacidad del impúber, o lo que es lo mismo, la capacidad para actuar «por sí mismo» encargándose en todo momento de gestionar su patrimonio.

Con la denominación de «impúberes», se aludía a las personas jóvenes que no habían alcanzado la edad de la pubertad. Las mujeres eran púberes al cumplir los 12 años de edad. Mientras que en el caso de los varones, la pubertad fue, conforme a la costumbre romana, objeto de reconocimiento por la familia, y era celebrada con una fiesta familiar con la correspondiente imposición de la toga viril lo que presuponía la mayoría de edad y la plena capacidad de obrar de la persona, en el caso de que ésta no se hallase sometida a potestad ajena ${ }^{14}$. Al final de la República, se manifestó la tendencia a fijar la pubertad de los varones, al cumplir éstos los 14 años de edad ${ }^{15}$.

En atención a la forma de designarse el tutor, la tutela se clasifica en testamentaria, legítima y dativa. La tutela testamentaria, era la ordenada en testamento por el paterfamilias respecto de los hijos que, estando bajo su patria potestas, se convertían, después de que él muriera, en sui iuris ostentando, pues, capacidad jurídica pero no capacidad de obrar hasta que ésta fuera adquirida con la pubertad ${ }^{16}$.

${ }^{13}$ En este sentido, CENDON, P. (ob. cit., p. 183) apunta que «las funciones del tutor impúber considerado un munus publicum, se explicaban en una serie articulada de cometidos y retribuciones que afectaban por un lado a la persona y por otro al patrimonio de la persona sujeta a tutela». En la misma línea, ZANINNI, P. (Studi sulla Tutela Mulierum, G. Giappichelli, Torino, 1976, p. 73) manifiesta que «se trata de asegurar al pupilo sui iuri la presencia de una persona idónea para que le guíe hasta alcanzar la pubertad». Por su lado, GARCÍA GARRIDO, M.J. (Diccionario de Jurisprudencia Romana...cit., p. 346) distingue dos clases de impúberes sometidos a tutela: a) Los infantes, que son los que no pueden hablar razonablemente (menor de 5 o 7 años) b) Los infantia mayores, que son responsables de los delitos y pueden intervenir en actos jurídicos en los que el tutor les asiste mediante auctoritas. En esta línea se pronuncian también DÍAZ-AMBRONA BARDAJÍ ( $\mathrm{M}^{\mathrm{a}}$. D.) y HERNÁNDEZ GIL (F.): Lecciones de Derecho de Familia, $2^{\mathrm{a}}$ ed., Universitaria Ramón Areces, Madrid, 2007, p. 480; e IGLESIAS REDONDO, J.: ob. cit., p. 360.

${ }^{14}$ FERNÁNDEZ DE BUJÁN, A.: ob. cit., p. 211.

${ }^{15}$ En este sentido, SHULZ, F.: Derecho Romano Clásico, trad. por Santa Cruz Tejeiro (J.), Bosch, Barcelona, 1960, p. 156; y SANZ MARTÍN, L.: ob. cit., pp. 69 y ss.

${ }^{16}$ Véase, GARCÍA GARRIDO, M.J., (Derecho Privado Romano, Acciones. Casos. Instituciones..., cit., p. 369) que manifiesta un cierto sentido lógico al nombramiento del tutor a favor del paterfamilias, toda vez que, como apunta, «la tutela originaria era consecuencia de la unidad del patrimonio familiar bajo la suprema autoridad del paterfamilias. Cuando éste falta es necesario que nombre otra persona para proteger y defender a los sometidos que carecen de capacidad para administrar el patrimonio familiar»; y FERNÁNDEZ DE BUJÁN, A.: ob. cit., p. 213. 
En esta época, resultaba impensable que la madre pudiera ejercer la patria potestas, y nombrar en consecuencia un tutor para sus hijos. El ejercicio de la tutela era considerado un cargo exclusivo de hombres, salvo que se solicitara expresamente al príncipe la tutela de los hijos $^{17}$. De ahí que, si un padre encomendaba en su testamento como tutor de los hijos comunes a la madre, el gobernador de la provincia no lo admitiese, ignorándose en este sentido la voluntad del padre ${ }^{18}$.

De lo expuesto se deduce la escasa consideración social de las mujeres que llegaban a ser privadas, sin motivo alguno, del derecho y deber que constituye la guarda y cuidado de un hijo.

Una vez que un hombre era designado tutor por testamento, dicho cargo se ejercía automáticamente desde el mismo instante en que éste cobraba eficacia sin que fuera requerida ni la confirmación por la autoridad, ni aceptación por parte de la persona designada ${ }^{19}$. Sin embargo, esta última podía, ciertamente, rechazar la tutela. Eso sí, la excusa de la tutela determinaba la privación para los hijos del que la ejercitaba de los bienes que les hubieran sido legados a éstos en atención al cargo asumido por su padre ${ }^{20}$.

En el supuesto de aceptación del cargo, los tutores nombrados en el testamento no venían obligados a prestar fianza, pero, si alguno la ofrecía, había de ser oído ${ }^{21}$.

${ }^{17}$ D. 26, 1, 18: «Feminae tutores dari non possunt, quia id munus masculorum est, nisi a Principe filiorum tutelam specialiter postulent». (Las mujeres no pueden ser nombradas tutoras porque este cargo es de hombres; a no ser que especialmente pidan la tutela de los hijos).

En este sentido, véase también SHULZ, F.: ob. cit., p. 158.

${ }^{18}$ D. 26, 2, 26: "Iure nostro tutela communium liberorum matri testamento patris frustra mandatur; nec si provinciae Praeses imperitia lapsus patris voluntatem sequendam decreverit, sucesor eius sententiam, quam legis nostrae non admittunt, recte sequetur». (Por derecho común no se puede mandar en el testamento del padre que la madre administre la tutela de los hijos comunes y si el Presidente de la provincia por impericia determinase que se observe la voluntad del padre, su sucesor no deberá observar la sentencia, que es contra nuestras leyes).

19 Vide SHULZ, F.: ob. cit., p. 158.

${ }^{20}$ D.26.2.28: «Qui tutelam testamento mandatam excusationis iure suscipere noluit, ab his quoque legatis summovendus erit, quae filiis eius relicta sunt, modo si legata filii non affectione propria, sed in honores pratis meruerunt» («Si el tutor testamentario no quisiese aceptar la tutela, proponiendo excusa para no serlo, ha de ser privado también de lo que se legó a sus hijos, si no se les legó por afecto a ellos, sino por contemplación del padre»). En el mismo sentido se pronuncia FERNÁNDEZ DE BUJÁN, A. (ob. cit., p. 213) que expone la posibilidad de que el tutor testamentario renuncie al ejercicio de la tutela mediante la abdicatio tutelae.

${ }^{21}$ D. 26, 2, 17: «Testamento datos tutores non esse cogendos satisdare rem salvam 
Podía darse el supuesto de una tutela plural. Nos encontramos ante una pluralidad de tutores en aquella situación en la que originariamente, o por causas sobrevenidas, resulten llamados, nombrados o designados (según que la tutela sea testamentaria, legítima o dativa) más de una persona para desempeñar simultáneamente el cargo de tutor, independientemente de que todos los llamados, nombrados o designados ejerzan o no efectivamente los actos propios de la administración de la tutela a la que han sido convocados. Además, cabe tener en consideración que una tutela plural, evita la necesidad de agregar curadores al tutor ${ }^{22}$.

La tutela legítima es la deferida a falta de tutor testamentario, de acuerdo con el orden de llamamientos que rige en materia de sucesión ab intestato conforme a lo dispuesto en las XII Tablas; esto es, se encargaba a los agnados, parientes paternos, y también a los patronos, es decir, a los que podían ser llamados a la herencia legíti$\mathrm{ma}^{23}$.

El tutor legítimo asumía automáticamente el cargo desde el mismo momento en que surgía la necesidad de la tutela. Es decir, nadie nombraba tutores legítimos sino que lo eran por expreso llamamiento legal (Ley de las XII Tablas) ${ }^{24}$.

fore, certo certius est. Sed nihilominus, quum quis offert satisdationem, ut solus administret, audiendus, est, ut Edicto cavetur...». («A los tutores nombrados en el testamento, no se les ha de precisar a dar fianza de que entregarán la tutela sin disminución; y esto es lo más cierto; pero no obstante, cuando la ofrece alguno para administrar él solo, debe ser oído, según se previene en el Edicto...»).

${ }^{22}$ A este respecto, FERNANDEZ DE BUJÁN, F. (Contribución al estudio de la tutela testamentaria plural en Derecho Romano, Dykinson, Madrid, 1995, pp. 33, 34, 217 y 218) lleva a cabo un estudio profundo, y detallado sobre la materia manifestando que «la tutela testamentaria plural fue un supuesto frecuente en la configuración social de la tutela en Roma».

${ }^{23}$ D. 26, 4, 1: "Legitimae tutelae lege duodecim tabularum agnatis delatae sunt, etconsanguineis, item patronis, id est his, qui ad legitimam hereditatem admitti possint. Hoc suma providentia, ut, qui sperarent hanc successionem, idem tuerentur bona, ne dilapidarentur». (Las tutelas legítimas se encargarán a los agnados y a los consanguineos por la Ley de las XII Tablas; también a los patronos, esto es, a los que pueden ser admitidos a la herencia legítima. Esto por suma providencia para los que esperan suceder cuiden de que no se pierdan los bienes).

En el mismo sentido, BURDESE. A. (ob. cit., pp. 221 y 278) señala que: «A la tutela legítima del impúber emancipado son llamados por interpretación de las XII Tablas en base a la categoría de sucesores ab intestato fijados, el patrón y si éste ha muerto, sus hijos».

${ }^{24}$ A este respecto, BURDESE, A. (ob. cit., p. 278) señala que: «No se da acto de aceptación por parte del llamado a la tutela legítima, ya que es automáticamente investido de la misma...». 
El tutor legitimus no estaba obligado a administrar personalmente los bienes del pupilo, por lo que en el supuesto de que deseara asumir la administración de los mismos, los cónsules exigían (antes de conferirle ésta), una garantía para asegurar la integridad del patrimonio pupilar, es decir, una «cautium rem pupillo salvam fore»" El edicto del pretor no exigía la prestación de esta cautio al tutor legitimus, lo que demuestra que fueron los cónsules y no el praetur urbanus quienes impusieron a éste, la obligación de prestar la cautio ${ }^{26}$.

Frente a la tutela testamentaria en la que el tutor no debía prestar fianza, en la tutela legítima, el pretor determinaba si el patrono y sus descendientes debían dar caución o no, de modo que, si fuera persona honorable, se le dispensara de la caución y, máxime, si el patrimonio es módico ${ }^{27}$.

El tutor legítimo no tenía derecho a abdicar del cargo, siendo posible transferir la tutela a otra persona mediante una «in iure cessio ${ }^{28}$. En el caso en que no se encontrara al sujeto al que poder transmitir la tutela, el tutor legitimus continuaba siéndolo. Esta obligatoria prosecución en el cargo, no resultaba dura por no estar el tu-

En el mismo sentido D. 26, 4, 5: «Legitimos tutores nrmo dat, sed lex duodecim tabularum fecit tutores...» («Ninguno nombrará a los tutores legítimos, porque la Ley de las XII Tablas los hizo tutores...».

${ }^{25}$ En este sentido, JORS (P.) y KUNKEL (W.): Derecho Privado Romano, $2^{\mathrm{a}}$ ed., trad. del alemán por Prieto Castro (L.), Labor, Barcelona, 1937, p. 426; SOLAZZI, S.: Console e pretore urbano nella datio tutoris, Archivio Giuridico, 85, 1921, pp. 279 y ss.; y TORRENT, A. (Diccionario..., cit., pp. 156 y 157): «...El pretor introdujo en época republicana esta cautio o satisdatio rem pupillo salvam fore (promesa de dejar a salvo los bienes del pupilo) con la que el tutor prometía administrar el patrimonio pupilar actuando con toda la diligencia que exigía el cargo...».

${ }^{26}$ Vide SHULZ, F.: ob. cit., p. 165.

${ }^{27}$ D. 26, 4, 5: «... (1)Sed etiam hos cogi satisdare certum est in tantum, uy etiam patronum et patroni filium, ceterosque liberos eius cogi rem salvam fore satisdare, plerisque videatur. Sed hoc causa cognita Praetorem statuere debere melius est, utrum debeat satisdare patronus liberique eius, an non, ut si pesona honesta sit, remittatur ei satisdatio, et maxime si substantia modica sit...». (... (1) También es cierto que esos están obligados a dar fianza, en tanto grado, que el patrono, y el hijo de éste, y los demás descendientes de él, están obligados, según la opinión común, a dar fianza de que permanecerá sin disminución el patrimonio del pupilo; pero es más conveniente que determine el Pretor con conocimiento de la causa, si debe dar fiador o no los Patronos y sus descendientes, para que le releve de ella si es persona honesta, particularmente si es corto el patrimonio...).

${ }^{28}$ Vide, entre otros, FERNÁNDEZ DE BUJÁN, A.: La Jurisdicción voluntaria, Civitas, Madrid, 2001, p. 63 y ss.; SHULZ, F.: ob. cit., p. 159; y BURDESE, A.: ob. cit., p. 278. 
LA PROTECCIÓN JURÍDICO-PATRIMONIAL DEL MENOR Y DEL INCAPACITADO ...

tor obligado a ejercer la tutela, ya que dicha tutela era un mero Munt $^{29}$.

Finalmente, la tutela decretalis o dativa surge en Roma con la Lex Atilia (entorno al año 210 a.C.) ${ }^{30}$, y tiene lugar en aquellos casos en los que el tutor es designado por el magistrado. Es en este momento cuando la visión estrictamente familiar de la tutela queda sustituida por una intervención creciente de la autoridad pública sobre el control del régimen tutelar ${ }^{31}$.

La Ley Atilia ordenaba al praetur urbanus el nombramiento de un tutor cuando el impúber careciese de tutor testamentarius y de tutor legitimus, cualquiera podía pedir al magistrado que se procediese al nombramiento de un tutor para el impúber ${ }^{32}$.

En estos supuestos, el magistrado nombraba al tutor mediante una orden especial, con la expresión «tutorem do». Una vez nombrado, el tutor decretalis se hallaba desde un principio obligado a actuar como tutor, pues la finalidad del nombramiento no podía ser la de otorgar un mero título. Por esta razón, la persona a quien el magistrado intentaba nombrar tutor podía excusarse alegando ciertas razones (causae excusationis), que, después de ser examinadas eran aceptadas o rechazadas por el magistrado. Incluso un tutor ya nombrado, podía alegar una excusa y si el magistrado la hallaba fundada, dicho tutor era destituido del cargo ${ }^{33}$.

El cargo de tutor dativo era considerado como un honor fruto de la confianza que se depositaba en la persona del tutor; así pues, se configuraba como una función privada y personal ${ }^{34}$. Sin embargo,

${ }^{29}$ El Munt conocido por las fuentes romanizadas como mundium, era el equivalente germánico al paterfamilias latino, es decir, a la potestad jurídicamente atribuida al cabeza de familia sobre el círculo de miembros que la integran. El Munt, en particular, se atribuía al jefe de la sippe sobre todos sus componentes otorgándole un poder que iba mucho más lejos que la simple patria potestad del Derecho romano (tanto en la potestad concedida, como en el grado de intervención tuitiva sobre el colectivo bajo su Munt).

${ }^{30}$ La fecha de la Ley es desconocida, pero como Livio, en su referencia del Senatusconsultum de Baccanalibus (186 a. C.) menciona un tutor Atilianus (39.9.7), la Lex Atilia debe ser anterior al año 186.

${ }^{31}$ Ésta constituye la interpretación más generalizada en la doctrina; así, por ejemplo SOLAZZI, S.: Studi sulla tutela, Pubblicazioni della facoltà di giurisprudenza dell'Università di Modena, Modena, 1925, p. 29 y ss.

${ }^{32}$ En este sentido, SHULZ, F.: ob. cit., pp. 156-159; y BURDESE, A.: ob. cit., p. 279.

${ }^{33}$ Véase SHULZ, F.: ob. cit., p. 161.

${ }^{34}$ Así bien, se pronuncian, entre otros, KASSER, M.: Das Römische Privatecht (ersterAbscnnitt) Das altro Mische das bor klassische und das klassische Recht, C.H. Verlag, Munich, 1971, pp. 356-359. 
cuando se recibían quejas de su conducta, el pretor urbano y el que presidía la provincia (en ejercicio de su imperium), tenían el poder y las medidas para ejercitar sobre el tutor la presión oportuna ${ }^{35}$.

Cabe señalar, por tanto, como consecuencia de la intervención de la autoridad pública una línea tendente a eliminar ese aspecto egoísta de la tuición, para convertirla en un deber o carga pública que recae sobre el que es nombrado tutor ${ }^{36}$.

Llevado a cabo un breve análisis de la tutela impuberum tratamos de encontrar la verdadera justificación histórica de la tutela de la mujer en Roma. La antigua voluntad normativa restringía la titularidad de ciertos derechos por parte de la mujer, impidiendo que ésta pudiera libremente disponer sin algún tipo de control de sus propios bienes ${ }^{37}$.

En este sentido, se hace eco, pues, la limitación de la capacidad de obrar de la mujer en época romana, siendo, además, sujeto pasivo de una serie de incapacidades jurídicas especiales ${ }^{38}$. Tal era así que, el marido antes de morir podía designarle tutor e, incluso, escogerle un segundo marido ${ }^{39}$. También contaba con el derecho de repudiar a la mujer, ya fuera en caso de esterilidad (pues no conviene que la familia se extinga), o bien en caso de adulterio, porque la familia y la descendencia deben conservarse puras de cualquier alteración ${ }^{40}$. Sin

35 SOLAZZI, S.: Istituti tutelari, Nicola Jovene, Napoli, 1929, p. 22.

${ }^{36}$ D'ORS, A.: Derecho privado romano, 5a ed., Pamplona, 1983, p. 357; y FERNÁNDEZ DE BUJÁN, A. (ob. cit., p. 215) manifiesta una flexibilización de la función egoísta de la tutela en sus orígenes al afirmar que «las amplias facultades del tutor de administración y gestión de los bienes del pupilo, fueron objeto de una progresiva limitación en el curso de la evolución histórica».

${ }^{37}$ En este sentido se pronuncia ALBANESE, B. : Le persone nel Diritto privato romano, Pubblicazioni del seminario giuridico dell'Università di Palermo, Palermo, 1979, p. 531; FERNÁNDEZ DE BUJÁN, A.: ob. cit., p. 198.

${ }^{38}$ Véanse, GARCÍA GARRIDO, J.M. (El Senadoconsulto Veleyano, en Miscelánea Romanística, vol. II, ed. Universidad Nacional de Educación a Distancia, Madrid, 2006, p. 641) nos habla del SC. Veleyano, que prohibió la intercessio pro aliis de las mujeres, es decir, prohibía a la mujer actuar en negocios que eran considerados como virilia officia, entre los que incluía la intecessio; TALAMANCA, M.: Elementi di Diritto Privato Romano, Giuffrè, Milano, 2001, p. 91; y FERNÁNDEZ DE BUJÁN, A. (ob. cit., p. 200) nos habla de una serie de limitaciones a la actuación de la mujer en Roma tanto en el ámbito público como en la esfera de derecho privado.

${ }^{39}$ DEMOSTHENE CONTRE APHOBOS I (Plaidoyers civils I, XXVII, Action de tutelle, Les belles lettres, Paris, 1954, p. 33 y 34): «...notre parenté étant ainsi renforcée, la tutelle n'en serait que mieux gérée». (...nuestro parentesco de ese modo resulta reforzado, y la tutela a resultas de ello sería mejor gestionada...).

${ }^{40}$ FUSTEL DE COULANGES: La ciudad antigua, trad. de Ciger Aparicio, (M.), ed. Daniel Jorro, Madrid, 1920, p. 116. 
embargo, si jurídicamente la manus suponía sometimiento, obediencia y sumisión de la mujer al paterfamilias, socialmente la mujer gozaba de la más alta consideración siendo la digna compañera del marido $^{41}$.

Por otro lado, la labor desempeñada por el tutor mulieris era igual que la propia del tutor impuberis, es decir, ambas clases de tutores llevaban a cabo tanto la auctoritas interpositio (complemento a la capacidad del tutelado) como la negotiorum gestio (administración de los bienes del tutelado).

Avanzando en la historia, los mismos romanos no han sabido darnos una razón plausible a la vigente «todavía» tutela mulieris en el derecho clásico siendo así que su abolición se sentía como una necesidad desde el final de la República. La respuesta es sencilla, ya que teniendo en cuenta los turbulentos tiempos que se vivían, los romanos no estimaron conveniente abolir la tutela y tampoco su supresión, al ser conscientes de las medidas verdaderamente reaccionarias ordenadas por Augusto ${ }^{42}$. Sin perjuicio de lo anterior, la situación de la mujer romana, experimenta una clara evolución con respecto a la época antigua, adquiriendo un marcado carácter de independencia. Así pues, al tutor mulieris no le competía la directa gestión del patrimonio de la mujer ${ }^{43}$, sino que se limitaba a prestar la auctoritas interpositio, dando su consentimiento para la realización de la mujer de determinados $\operatorname{actos}^{44}$. Por consiguiente, si bien en los primeros tiem-

${ }^{41}$ GARCÍA GARRIDO, M.J.: La convivencia en la concepción romana del matrimonio, en Miscelania Romanística, vol II, ed. Universidad Nacional de Educación a Distancia, Madrid, 2006, p. 656.

${ }_{42}$ Véanse SHULZ, F.: ob. cit., pp. 171 y 172; y BONFANTE, P.: ob. cit., pp. 557 y 558.

${ }^{43}$ GAYO (I, 190): «...mulieres enim, qua perfectae eatatis sunt, hipase sibi negocia tractant...». (...pues las mujeres de plena edad realizan los negocios por sí mismas...).

En el mismo sentido, FUENTESECA, P. (ob. cit., p. 413): «En época clásica el tutor mulieris no aparece con potestad sobre la persona o los bienes de la mujer, cuyos negocios no gestiona».

${ }^{44}$ GAYO (I, 115): "...si qua uelit quos habet tutores deponere et alium nancisci, illis auctoribus coëmptionem facit; deinde a coëmptionem remancipata ei, cui ipsa velit, et ab eo vindicta manumissa incipit eum habere tutores, a quo manumissa est; qui tutor fiduciarius dicitur, sicut inferius apparebit». (Cuando una mujer quiere dejar a los tutores que tiene y obtener otro, se hace, con la autorización de aquellos, la compra, después el comprador lo vende nuevamente a quien ella escoja, y una vez que es manumitida por éste, entra en la tutela de este que la manumitió; el cual tutor se llama fiduciario, como se verá después).

En el mismo sentido, BURDESE, A. (ob. cit., pp. 276 y 277) expone la necesidad de que la auctoritas interpositio del tutor permanezca limitada a determinados actos, 
pos la función de la mujer era la de señora de la casa a la sombra del paterfamilias, a finales de la República actúa ya autónomamente en determinados actos, relajándose los vínculos potestativos que limitan su campo de actuación.

La emancipación de la mujer se produce definitivamente en la última centuria antes de Cristo. Comienza a participar en la vida pública (si bien sigue siendo excluida de los Comicios, Senado y Magistraturas), encontrando en el Estado amparo contra los abusos del hombre. Pese a los logros, Roma no reconoció nunca la influencia ejercida por la mujer; este reconocimiento realmente se producirá en el cristianismo, al declarar a la mujer como madre del eterno ${ }^{45}$.

No se puede negar, sin embargo, que en la evolución del Imperio Romano, se produjo un paso importante para el reconocimiento de la mujer como individuo activo en la sociedad, sujeto tanto de deberes como de derechos. Podemos, pues, distinguir dos fases o etapas que marcan, sin duda, la historia tutelar de la mujer en Roma: la primera, la tutela mulieris originaria en la que existe todo un régimen de limitación de la capacidad de la mujer que impone la actuación del tutor en los actos más importantes de disposición para la custodia y conservación del patrimonio familiar; y la segunda, el régimen clásico de la tutela, mera supervivencia formal que sigue manteniéndose cuando el primitivo régimen familiar desaparece y cuando los tiempos claman una mayor libertad respecto a la actua-

entre los cuales destacamos la adquisición de la manus de la mujer; alienación de res mancipi; legis actio y por lo tanto, in iure cessio; constitución de dote; manumisión; testamentos; asunción de obligaciones, etc; y CENDÓN, P. (ob. cit., p. 183) nos señala al respecto que "las funciones del tutor mulieris se concretan... en un simple y limitado poder de control que excluía a priori cualquier directa intervención en los asuntos de la mujer».

${ }^{45}$ A este respecto, se pronuncia PARRA MARTÍN, $\mathrm{M}^{\mathrm{a}}$. D. (Mujer y Concubinato en la Sociedad Romana, Anales de Derecho, Universidad de Murcia, $n^{\circ} 23,2005$, p. 241): Caecina Severus (20 d. C.) pronunció una violenta oración contra la actividad política de las mujeres de los gobernadores de provincia (TAC Ann. 3. 33): «Las mujeres actuaron en negocios como la mujer de Cicerón, Terencia que administró sus bienes valiéndose de la ayuda de sus libertos».

${ }^{46}$ Sobre la tutela de la mujer y sus distintos problemas, véase GARCÍA GARRIDO, M.J.: Derecho Privado Romano. Casos. Acciones. Instituciones..., cit., pp. 373 y 374. También apuntan este tipo de problemas juristas extranjeros como, GIDE, P.: Etude sur la condition privée de la femme dans le droit ancien et moderne et en particulier sur le sénatus-consulte Velléien, Paris, 1885, p. 102 y ss.; SOLAZZI, S.: Sulle tracce del tutor mulieris, en Studi sulla tutela, 1925, p. 16 y ss.; TAUBENSCHLAG, R.: Vormundschaftsrechtlichen Studien, Beiträge zur Geschichte des römischen, und griechischen Vormundschaftsrechts, Leipzig, Berlín, 1913, pp. 83 y ss. 
ción de la mujer ${ }^{46}$. A medida que la antigua comunidad familiar se disgregaba, el régimen de la tutela mulieris pierde su razón de ser y a través de sucesivas modificaciones, que intentan adaptarla a las condiciones sociales, del momento, acaba siendo un relicto histórico que, reducido a una mera limitación formal, termina siendo abandonado ${ }^{47}$. En palabras de FERNÁNDEZ DE BUJÁN, «...no es la biología, ni la moral, ni la capacidad intelectual, lo que ha determinado las limitaciones que han padecido las mujeres en la sociedad romana, sino que ello obedece a razones culturales o sociales, que en el mundo romano se derivan de la concepción patriarcalista de la familia, que progresivamente atenuada en el propio Derecho Romano, ha subsistido prácticamente hasta casi nuestros días, así como a otras variadas pseudorazones, alguna de las cuales obedece a las coordenadas mentales de la época, como la necesidad de protección de la mujer y otras, producen sólo sonrojo, como la fragilidad somática o su volubilidad de juicio» ${ }^{48}$.

En definitiva, tanto la tutela impuberis como la tutela mulierum son reflejo de aquellos tiempos en los que la institución tutelar no era una figura impregnada de deberes, sino que al contrario, consagra el derecho del tutor y su poder de maniobra y gestión sobre la persona del tutelado.

La curatela cuenta con un largo recorrido a lo largo de nuestra historia jurídica, ya que, si bien en tiempos romanos era conocida y aplicada, en el siglo XIX había sido rechazada conscientemente por el legislador del Código civil. La Ley de las XII Tablas ponía únicamente bajo curatela a los locos cuya incapacidad era absoluta por carecer de voluntad, y a los pródigos ${ }^{49}$ que disipaban los bienes que habían recibido como herederos abintestato de un ascendiente.

La curatela consistía en un cargo público que obligaba a una persona designada por la ley o por el magistrado a dirigir la administración de los bienes de un sui iuris púber e incapaz de ejercer por

${ }^{47}$ GARCÍA GARRIDO, M.J.: El patrimonio de la mujer casada en el derecho civil. I La tradición romanística, Dykinson, Madrid, 1982, p. 115.

48 FERNÁNDEZ DE BUJÁN, A.: ob. cit., p. 200. Vide, también, BURDESE, A. (ob. cit., p. 277), afirma que la tutela mulieris desaparece definitivamente en el siglo V d. C. sin dejar huella ni en el Código Teodosiano ni en el Corpus iuris justinianeo»; y GARCÍA GARRIDO, M.J.: El patrimonio... cit., pp. 142 y 143.

${ }^{49}$ Una definición acertada de pródigo nos la ofrece FERNÁNDEZ DE BUJÁN, A. (ob. cit., p. 220) al apuntar que son aquellas personas que dilapidan sus bienes sin medida, poniendo a su familia, y a sí mismo, en riesgo de subsistencia. 
sí sólo sus derechos; el curador era el representante del menor y disponía de su patrimonio en lugar y nombre de éste ${ }^{50}$.

La ley encomendaba la curatela del patrimonio del loco, al agnado próximo o a los gentiles. El curador actuaba siempre en nombre del incapaz, cuidando de su persona y administrando su patrimonio (interdicto bonis). En cuanto a la curatela de los pródigos (cura prodigi), ésta, recaía sobre aquellas personas que por dilapidar sus bienes habían sido declarados incapacitados para administrar su propio patrimonio. El curador intervenía sólo en los negocios que reflejaban una obligación o una disposición, no en los que suponían un incremento patrimonial ${ }^{51}$.

En el Derecho clásico, el curador representaba simplemente la «garantía moral» de los actos llevados a cabo por el menor, quién era perfectamente capaz de realizarlos por si sólo. Sin embargo, en el Derecho justinianeo el curador no sólo se limitaba a prestar su asistencia para la realización de los actos del menor, sino que también administraba el patrimonio del mismo ${ }^{52}$.

Ambas instituciones de guardaduría han venido confundiéndose a lo largo de la evolución histórica, si bien se diferenciaban no sólo por su objeto (la tutela buscaba el cuidado de la persona y de sus bienes, mientras que la curatela perseguía únicamente el de los bienes), sino también por su contenido; así, mientras que la tutela consistía en la cooperación del tutor en la celebración de actos jurídicos (auctoritas interpositio), a la que, en ocasiones, podía ir unida la gestio (administración de los bienes y celebración de actos jurídicos en nombre y sin intervención del pupilo), en la curatela, ésta, era esencial. La persona incapaz quedaba sometida a una u otra institución de guarda, en atención a sus concretas necesidades, así, quedaban sujetos a tutela los huérfanos menores de doce años (impúberes), y a curatela los huérfanos púberes menores de veinticinco años y los incapaces.

Antes de iniciarse el ejercicio, el tutor debía redactar el inventario de los bienes del pupilo, en forma solemne y en presencia del juez ${ }^{53}$.

${ }^{50}$ GARCÍA GARRIDO, M.J.: Derecho Privado Romano..., cit., pp. 249 y 250; TORRENT, A.: Manual.... cit., pp. 561 y ss.; y CENDON, P.: ob. cit., p. 183.

${ }^{51}$ GARCÍA GARRIDO, M.J.: Diccionario de Jurisprudencia Romana ..., cit., p. 88.

52 SARGENTI, M.: Il diritto Privato nella legislazione di Costantino, Persone e Famiglia, Giuffrè, Milano, 1938, p. 149.

${ }_{53}$ Partida 6a , título XVI, ley 15: "Debe el tutor hacer luego inventario de los bienes del menor con autoridad del Juez del lugar, y por mano de escribano público; incluyendo en él todos los privilegios y cartas de las heredades: no haciéndolo así, puede ser removido de la tutela como sospechoso, si no muestre justa razón por que no pudo hacerlo...». 
$\mathrm{Al}$ concluir el mismo, debía rendir cuentas y entregar los bienes al pupilo o curador ${ }^{54}$. Así, pues, el tutor respondía con sus bienes de la integridad del patrimonio del huérfano y de los bienes y derechos que fueran incluidos por él en la escritura de inventario.

En Roma, concretamente en la época clásica, la institución tutelar experimenta una notable evolución. Con la llegada de la República, los fines egoístas de la tutela van pasando a un plano secundario, y la tutela-derecho va evolucionando hacia una tutela carga u obligación, impuesta en interés público, que grava al que la ejercita ${ }^{55}$.

La intervención de la autoridad aumenta y con ello, su responsabilidad; por tanto, la participación del Estado en la organización de la tutela era cada día mayor y las facultades del tutor como gestor de los bienes pupilares tendían a ser cada vez más reducidas, exigiéndole autorización para realizar enajenaciones de cierta importancia ${ }^{56}$. Observamos, pues, como la tutela va asumiendo el carácter de deber público, sin ser lícito sustraerse de dicho deber, sino por causas de exención debidamente comprobadas por el magistrado. La autoridad judicial va asumiendo un papel importante frente a etapas anteriores en que su labor estaba dotada de una menor relevancia.

A estos efectos, la institución tutelar trataba de impedir que los actos del pupilo menoscabasen su patrimonio, de ahí, que el fundamento de la auctoritas interpositio consistiera en complementar al impúber para constituir ambos (tanto tutor como pupilo) una figura jurídica. En otras palabras, no puede hablarse de dos personas, sino de una jurídica, compuesta de dos físicas que se complementan ${ }^{57}$.

${ }^{54}$ Partida 6 ${ }^{\mathrm{a}}$, título XVI, ley 21: "...ha de dar buena cuenta de los bienes del menor, y entregarlos a su curador; y a este fin son obligados él, sus fiadores y herederos con todos sus bienes a favor del huérfano y herederos de éste».

${ }^{55}$ En este sentido, véanse, SOLAZZI, S.: Istituti tutelari..., cit., p. 10; y KASER, M.: ob. cit., p. 286; FERNÁNDEZ DE BUJÁN, A. (ob. cit., p. 213) apunta que la tutela de los menores, concebida durante siglos como un poder que se atribuye al tutor evolucionó al considerar prevalerte la defensa de los intereses del pupilo y pasó de ser una carga a reconocerse como un derecho; y RODRÍGUEZ-ARIAS BUSTAMANTE, L.: La Tutela. Bosch, Barcelona, pp. 58 y 59.

${ }^{56}$ Un Senatus Consultum de Septimio Severo (195 d. C.), prohíbe al tutor enajenar y gravar praedia rustiva ver suburbana, propiedad del pupilo, a no ser que el padre hubiera autorizado la operación por testamento. Si la enajenación era necesaria para pagar deudas del pupilo, el tutor debe obtener un permiso especial.

Véase, a este respecto, SHULZ, F.: ob. cit., p. 166.

${ }^{57}$ Vide RODRÍGUEZ-ARIAS BUSTAMANTE, L.: ob. cit., p. 60. 
El negotorium gestio consistía en la actividad de una persona (negotiorum gestor) que, sin haber recibido mandato alguno ni estar obligado, gestiona negocios de otra (dominus negotii). Dicha acción se realizaba siempre a favor del interés objetivo del patrimonio del dominus o principal y debía reportar una utilidad, esto es, bastaba que el gestor hubiera actuado útilmente (utiliter gestum), aunque no llegara a tener efecto el negocio ${ }^{58}$.

La tutela aún considerada originariamente como un derecho, en cuanto gestión de un patrimonio, debía ser ejercitada honradamente; por ello, en las XII Tablas se encuentran establecidos dos procedimientos contra los tutores que con su conducta al frente del patrimonio que se les confiaba faltaban gravemente a aquel deber. Estas dos acciones eran la «accusatio suspecti tutoris ${ }^{59}$ y la «actio de rationibus distrahendis» ${ }^{60}$.

La primera servía para lograr la destitución del tutor designándose otro. El jurisconsulto GAYO hace referencia a ésta estableciendo que si un tutor hubiese sido removido de la tutela del pupilo por

${ }^{58}$ D. 3, 5, 9: «Pomponius scribit, si negotium a te, quamvis male gestum, probavero, negotiorum tamen gestorum te mihi non teneri. Videndum ergo, ne in dubio, hoc an ratum habeam, actio negotiorum gestorum pendeat; nam quomodo, quum semen coeperit, nuda voluntate tolletur? sed superius ita verum se putare, si dolos malus a te absit. Scaevola: imo puto, etsi comprobem, adhuc negotiorum gestorum actionem esse; sed eo dictum, te mihi non teneri, quod reprobare non possin semen probatum, et quemadmodum, quod utiliter gestum est, necesse est apud iudicem pro rato haberi, ita omne, quod ab ipso probatum est. Certerum si, ubi probavi, non est negotiorum actio, quid fiet, si a debitore meo exegerit, et probaverim, quemadmodum recipian? item si venderit?ipse denique, si quid impendit, quemadmodum recipient? Nam utique mandatum non est: erit igitur et post ratihabitionem negotiorum gestorum actio». (Escribe Pomponio, que aunque apruebe la mala gestión, que hiciste en mi nombre, no se te dará contra mí la acción que resulta de la gestión de los negocios. En esta duda se ha de ver, si la acción que resulta de la gestión, pende de si hubo ratificación; porque si la hubo, ¿cómo se ha de revocar por sola la voluntad? Y juzga que será cierto lo expresado, si en ti no hubo dolo malo. Escevola juzga, que aunque haya ratificación, no resultará acción de la gestión de los negocios; y por eso se ha dicho que tu no me estas obligando, porque no puedo reprobar lo que una vez aprobé; y al modo que es necesario que ratifique ante el juez la gestión útil, es también necesaria la de todo lo que yo mismo aprobé; pero si al tiempo de la aprobación no se verificó la acción que resulta de la gestión de los negocios, ¿qué se dirá si cobro de mi deudor, y yo lo aprobase? De que modo lo pediré? y si también vendió? Y si finalmente hubiese hecho algunos gastos, ¿de que modo los repetirá? Porque ciertamente no ha intervenido mandato. Se dará, pues, la acción que resulta de la gestión de los negocios después de la ratificación).

59 TORRENT, A. (Diccionario..., cit., p 18): «Se atribuye a las XII Tablas la introducción de esta acción penal para exigir responsabilidad al tutor por la malversación dolosa de los bienes del pupilo en principio únicamente ejercitable contra el tutor testamentario...».

${ }^{60}$ ARIAS RAMOS, J.: ob. cit., p. 748. 
LA PROTECCIÓN JURÍDICO-PATRIMONIAL DEL MENOR Y DEL INCAPACITADO ...

sospechoso, o si se hubiera excusado en virtud de justa causa, habrá de ponerse otro en su lugar, con lo cual el tutor anterior pierde la tutela ${ }^{61}$.

La segunda era una acción penal que castigaba la sustracción de bienes cometida por el tutor, siendo condenado a pagar el doble del valor de los bienes sustraídos.

Tenemos que situarnos en los tiempos finales del periodo republicano para encontrarnos con una nueva acción, la «actio tutelae» ${ }^{2}$, que con algunas reformas y complementos, fijó de modo completo la responsabilidad del tutor.

Llegados a este punto, la tutela impuberum se daba por concluida una vez alcanzada la pubertad. Sin embargo, la tutela mulieris era una tutela perpetua, cayendo con el paso del tiempo en desuso. Por tanto, a partir de la nueva organización familiar, la tutela por el sexo no fue más que una supervivencia sin verdadera sustantividad.

A modo de conclusión, observamos como lentamente van cristalizando las limitaciones del poder tutelar en normas fijas de Derecho privado, las cuales imponen al tutor determinados deberes jurídicos. Las amplias facultades del tutor de administración y gestión de los bienes del pupilo, son objeto de una progresiva limitación en el curso de la evolución histórica.

\section{REGULACIÓN DE LA INSTITUCIÓN TUTELAR EN LOS DISTINTOS TEXTOS LEGISLATIVOS CIVILES.}

Durante el siglo XIX, las Partidas continuaban vigentes en España con su sistema de control judicial. Sin embargo, en el Derecho Medieval las provincias romanas se vieron invadidas por los pueblos germanos lo que trajo como consecuencia, en el campo del Derecho, la coexistencia de varios órdenes jurídicos; por una parte, el Derecho Romano, que acusa el fenómeno de la vulgarización; y por otra, las costumbres e instituciones aportadas por las inmigraciones

${ }^{61}$ GAYO (1, 182): "Praeterea Senatus censuit, ut si tutor pupilli pupillaeue suspectus a tutela remotus sit, siue ex iusta causa fuerit excusatus, in locum eius alius tutor detur; quo facto prior tutor amittit tutelam».

${ }^{62}$ FERNÁNDEZ DE BUJÁN, A. (ob. cit., p. 216) afirma que es la acción dirigida por el pupilo contra su tutor con la que se solicita no sólo la restitución de los bienes del pupilo, sino también los beneficios obtenidos por el tutor en el ejercicio de su cargo y la reparación de los daños que, en su caso, hubiere ocasionado. 
germánicas. Además, están presentes el Derecho canónico y el de ciertos grupos que ni se romanizan ni quedan sometidos a los pueblos bárbaros ${ }^{63}$.

Las normas del Derecho germánico vigente no eran tan completas como las romanas. No obstante, presentan una regulación bastante detallada, de la que dan cuenta las fuentes visigodas escritas; así, ocurre con el Fuero Juzgo (Libro IV, título III), el Fuero Viejo (Libro V, título IV) y el Fuero Real (Libro III, título VII). Estos textos recogen la concepción que los pueblos germanos tienen de la institución tutelar, que era de carácter colectivo, por corresponder a toda la familia; sin embargo, con el paso del tiempo, la tutela se fue atribuyendo al pariente más próximo, pero sin que por ello la familia dejara de tener un cierto poder de intervención.

En el primitivo Derecho germánico, solían quedar sometidas a la institución tutelar aquellas personas menesterosas de protección y desprovistas de una relación de mundium $^{64}$ paternal o marital en razón de la edad, el sexo o el estado de incapacidad. Bajo la tutela del sexo se encontraban las mujeres de por vida; sin embargo, los varones menores estaban sometidos a la tutela hasta que alcanzaban el mundium propio.

En un primer momento, los germanos asentados en las provincias romanas mantuvieron sus costumbres primitivas respecto a la protección de los menores e incapaces. La sippe englobaba al conjunto de parientes de sangre de un determinado individuo y operaba como una supratutela a la que correspondía la vigilancia y el derecho de otorgar consentimiento al pupilo para contraer matrimonio, enajenar sus bienes, y destituir al tutor en el caso de que éste no emplease la diligencia debida. La sippe designaba como tutor a una persona de su seno, que normalmente recaía en el pariente pars gladii más próximo del pupilo, es decir, el pariente masculino más cercano, que era el encargado de llevar a cabo la administración tutelar, ya que el poder pú-

${ }^{63}$ Vide GARCÍA GALLO, A.: Manual de Historia de Derecho Español, $3^{\mathrm{a}}$ ed., t. I, A. G. y E., Madrid, 1967, p. 55.

${ }_{64}$ El munt o mundium era la potestad jurídica (no propiedad) del señor de la casa sobre todos los integrantes de la comunidad doméstica (esposa señora de la casa, hijos, hermanas solteras, viudas, criados extranjeros hospedados, personas sometidas a tutela, incluso personas libres a las que se representa en la vida procesal en la medida en que la aceptan). El mundium excede, pues, de una simple relación del Derecho de familia para constituir el ejercicio de una potestad tuitiva y directiva muy amplia, que, precisamente, como consecuencia de su gran amplitud inicial, se irá escindiendo a lo largo de la historia en diferentes instituciones de Derecho privado. 
LA PROTECCIÓN JURÍDICO-PATRIMONIAL DEL MENOR Y DEL INCAPACITADO ...

blico carecía entonces de autoridad para intervenir en los asuntos tutelares $^{65}$. Por tanto, eran los parientes los encargados de elegir el tutor adecuado en caso de ausencia de testamento legítimo; y también ejercían derechos sobre los bienes del menor, con facultades, inclusive, para disponer de ellos. El juez aparece únicamente como testigo de los actos, pero carece de facultades decisorias ${ }^{66}$.

Sin embargo, es precisamente uno de los pueblos germanos, el franco, el que recibió la herencia del Derecho romano posclásico en esta materia. Como parte de esa herencia, reapareció la intervención pública sobre la tutela ${ }^{67}$. En este sentido, el poder público, en ocasiones, hacía suya por completo la supratutela, como ocurrió principalmente en lugares donde la tutela superior de la sippe había adquirido poca importancia hasta el punto de ver reducida su influencia a la propia de un órgano de administración, denominado Consejo de Familia ${ }^{68}$.

El Fuero Juzgo es el primer monumento legal hispano-godo en el que se esbozan las líneas fundamentales de nuestro Derecho: subordinación a la justicia divina, valor primario de la honra y dignidad de la persona humana, unidad de la fe y prevalencia de la moral ${ }^{69}$. En este Texto legal observamos que la regulación de la figura del tutor es limitada.

En España, durante la vigencia del Fuero Juzgo, los huérfanos menores de edad quedaban sometidos a la tutela ${ }^{70}$. Ésta era encomendada, en primer lugar, a la viuda; en su defecto, a los hermanos, y, a falta de éstos, a los hermanos de los padres, o a los hijos de éstos. No existiendo parientes en estos grados, era el juez quien nombraba un guardador para los pupilos ${ }^{71}$.

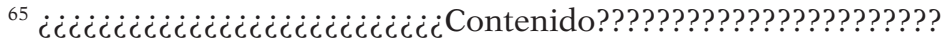

${ }^{66}$ Vide MERCHAN ALVAREZ, A.: La tutela de los menores en Castilla hasta finales del S. XV, Universidad de Sevilla, Sevilla, 1976, p. 192.

${ }^{67}$ WIEACKER, F.: Historia del Derecho Privado en la Edad Moderna, trad. por Fernández Jardón (F.), Comares, Granada, 2000, pp. 27 y ss.

${ }^{68}$ BRUNNER, H.: Historia del Derecho germánico, $8^{\mathrm{a}}$ ed., trad. por Álvarez López (J.L.), Labor, Barcelona, 1936, pp. 235 y ss.

${ }^{69}$ Véase LASSO GAITE, J.F.: Crónica de la Codificación Española 4, vol. I, Ministerio de Justicia, 1970, p. 23.

${ }^{70}$ Fuero Juzgo, libro IV, título III, ley $4 .{ }^{\text {a: }}$ «Porque los huérfanos mientra que son pequennos non pueden defender sus cosas ni á si mismos, derecho es que sean en guarda dotri fasta tiempo establescido».

${ }^{71}$ Fuero Juzgo, libro IV, título III, Ley $3 .^{\text {a: }}$ «Si el padre fuere muerto, la madre debe aver los fiios de menor edad en su guarda...E si la madre se quiere casar, é alguno de los fiios fuere de edad de XX annos fasta XXX, este debe aver los otros hermanos é las 
En este cuerpo legal, se mencionan como obligaciones del tutor la de hacer inventario de los bienes de los menores ${ }^{72}$, y responder en nombre de éstos de cuantas demandas se hicieran contra ellos ${ }^{73}$. Por el contrario, el tutor recibía por el ejercicio de su cargo el diezmo de los frutos y tenía también derecho al reintegro de las cantidades que hubiere gastado en el pupilo ${ }^{74}$.

El Fuero Viejo de Castilla constituía una colección particular de leyes castellanas reunidas con el fin de que sirvieran como un Código completo para los pueblos de señorío, de modo que los nobles no tuviesen que recurrir a las leyes comunes ${ }^{75}$. En este Fuero Viejo, la regulación de la tutela tampoco es abundante. El libro V, en su título IV, sus cuatro primeras leyes se agrupaban bajo la rúbrica «De la guarda de los huérfanos e de sus bienes». La Ley $1^{\mathrm{a}}$ regulaba "Cónmo se deven guardar e levar adelante los bienes de los huérfanos»; así, en caso de que los padres murieran dejando hijos menores de edad, serían los parientes más cercanos los que deberían hacerse cargo tanto de ellos como de sus bienes ${ }^{76}$. La Ley $2^{\mathrm{a}}$ enunciaba «Por quáles cosas se deven vender los bienes de los huérfanos», señalando que, en el caso en que no hubiera guardador, la justicia debería escoger al pariente más próximo, para vender sus bienes o para guardarlos ${ }^{77}$. La Ley $3^{\mathrm{a}}$, que lleva como rúbrica «Fasta quánto tiempo los menores de edat pueden empennar o vender lo suyo», manifestaba que ningún menor de edad podría dar, ni vender, ni enajenar, ni obligar ninguna de sus cosas hasta que cumpliere los

sus cosas en guarda, é non las dexar ennaienar ni perder á ellos ni á otri... E si los hermanos non fueren de tal edad, ó de tal discreción que devan aver los otros en guarda; entonze el tio ó el fiio del tio debe aver la guarda dellos en tal manera, cuemo dixiemos del hermano. E si el tio ó el fiio del tio non es tal, que lo deva aver, entonze el iuez lo dé á alguno de los otros parientes».

${ }^{72}$ Fuero Juzgo, libro IV, título III, Ley $3 .^{\mathrm{a}}{ }^{\text {: }}$ "E si la madre oviere la guarda de los fiios, ó quienquier otri, faga escripto de todas las cosas que dexó su padre á los huérfanos ante tres testimonios, ó cinco...».

${ }^{73}$ Fuero Juzgo, libro IV, título III, Ley $3 .^{\mathrm{a}}:$ " $E$ si algunas demandas fueren fechas contra los ninnos aquel que fuere su defendedor debe responder por ellos...».

${ }^{74}$ Fuero Juzgo, libro IV, título III, Ley 3. ${ }^{\text {a: }}$ «E mandamos que tome todo el diezmo del fructo en que viva, porque non faga grandes despensas en lo a. E si algunas despensas ficiere por los negocios de los hermanos de lo suyo, muéstrelo al iuez, é cobrelo de lo de sus hermanos comunalmientre».

${ }^{75}$ LASSO GAITE, J.F.: ob. cit., p. 26.

${ }^{76}$ Fuero Viejo de Castilla, libro V, título IV, ley $1^{\text {a }}$ : "Quando omne o muger muere e desan fijos chicos que non son de edat e déxalos el padre o la madre eredat o mueble, dévenlos tomar los parientes mas propincos a ellos e a sus bienes...».

${ }^{77}$ Fuero Viejo de Castilla, libro V, título IV, ley $2^{\mathrm{a}}$ : «...E. sy non oviere guardador, la justicia debe prendar al pariente más cercano, por que venda de sus bienes para conplir esto e para averlos en guarda». 
dieciséis años de edad ${ }^{78}$. Finalmente, la Ley $4^{\mathrm{a}}$ se refería a «De cónmo deven rrazonar por los huérfanos, sy les ficieren demanda», de manera que, en el supuesto de que alguien reclamara algo a un huérfano, debería dirigirse al pariente más cercano ${ }^{79}$.

Como queda de manifiesto, el Fuero Viejo recoge con brevedad la figura del tutor y su deber de cumplir determinadas funciones sin hacer alusión alguna a sus derechos.

Por su parte, el Fuero Real fue redactado a mediados del siglo XIII y responde a la meritoria finalidad de unificar el Derecho roto por los fueros nobiliarios y locales ${ }^{80}$. Contiene reglas relativas a las instituciones de guardaduría muy parecidas a las expuestas en el Fuero Juzgo; así, la tutela se confiaba, en primer lugar, a la madre siempre que ésta no contrajera segundas nupcias ${ }^{81}$. Si las contraía, los parientes procedían al nombramiento de un guardador, que debía recaer «en omne de XX annos, al menos, é deue ser cuerdo é de buen testimonio é abondado» (Libro III, título VII, ley 1. a). También alude el Fuero Real a la obligación del guardador de hacer inventario y rendir cuentas después de su gestión ${ }^{82}$; responder de cualquier demanda que se dirigiera contra los huérfanos ${ }^{83}$, así como al derecho que tiene a tomar para sí el diezmo de los frutos por razón de su trabajo ${ }^{84}$.

Dicho Fuero estuvo poco tiempo en vigor debido a la publicación del Código de las Siete Partidas, que establece una doctrina completa y ordenada de la guardaduría (Partida VI, títulos XVI, XVII, y XVIII).

${ }^{78}$ Fuero Viejo de Castilla, libro V, título IV, ley $3^{\mathrm{a}}$ : «Ningún ninno chico nin ninguna ninna chica ni ninguna huérfana nin ningún huérfano, fasta que aya dizyséis annos...non ayan poder de dar nin de vender nin de enagenar nin de obligar a pennos su heredamiento nin su mantenimiento nin ningunas de sus cosas».r

${ }^{79}$ Fuero Viejo de Castilla, libro V, título IV, ley $4^{\mathrm{a}}$ : «Que, sy algunos huérfanos, que non an tienpo, agún omne les quisiere fazer alguna demanda, debe ser llamado el más cercano pariente».

${ }^{80}$ LASSO GAITE, J.F.: ob. cit., p. 26.

${ }^{81}$ Fuero Real, libro III, título VII, ley 3. . $^{\text {: }}$ :Si el padre muriere e fiios fincaren sin edad, la madre non casando tome a ellos e a sus bienes si quisiere e téngalos en su guarda...».

${ }^{82}$ Fuero Real, Libro III, título VII, ley 2. ${ }^{\mathrm{a}}$ : «...Et quando uinieren a edad déxeles todo lo suyo antel alcalde por el escripto con que lo recibió et déles cuenta derecha de los fructos que ende recibió...».

${ }^{83}$ Fuero Real, Libro III, título VII, ley 2 . $^{\mathrm{a}}$ : «...e si alguna demanda finieren a los huérfanos o ellos ouieren a demandar a otri, aquel que los á en guarda pueda demandar e responder por ellos...».

${ }^{84}$ Fuero Real, Libro III, título VII, ley 2. ${ }^{\mathrm{a}}$ : «...e tome pora sí el diezmo de los fructos por razón de so trabaio». 
De lo que venimos exponiendo se desprende que, frente a la configuración romana de la institución tutelar, ésta presenta en el Derecho germánico las siguientes características:

a) La unidad institucional frente a la bifurcación romana; es decir, reunió en una sola institución las figuras de guarda, ya que desconoció la clasificación romana de tutela y curatela; b) Se atribuyó el ejercicio de la tutela a los parientes más próximos (tutela familiar colectiva); c) El llamamiento a la tutela es únicamente legal y, en su defecto, se defiere por la autoridad ${ }^{85}$.

En la Edad Moderna no habían desaparecido totalmente los elementos jurídicos romanos que coexistían con elementos germánicos; por ello, la tutela se organizaba siguiendo criterios de inspiración romana y germánica. Sin embargo, con la publicación del Código de las Siete Partidas ${ }^{86}$ en el reinado de Alfonso X el Sabio (alrededor del año 1265) se establece una doctrina completa y ordenada de la guardaduría (Partida 6 ${ }^{\mathrm{a}}$, títulos XVI, XVII, XVIII y XIX). Se omite toda esta rica gama de matices que ofrecen los Fueros españoles, introduciendo en su articulado las rígidas normas exóticas del Derecho Romano; esto es, la tutela unipersonal (excepcionalmente con pluralidad de tutores) y la distinción entre tutela y curatela.

Adentrándonos en un análisis más detallado del desarrollo de las instituciones de guardaduría en Las Leyes de Partidas, cabe señalar, como primer rasgo característico, la ya referida coexistencia de ambas instituciones de guarda (tutela y curatela) creadas para la protección de la persona y los bienes del pupilo menor o incapacitado, en la medida que se reputaba necesario. A este respecto, la tutela se estableció para huérfanos libres menores de 14 años, y para huérfanas menores de 12 años que no podían gobernarse por sí mismas; en cambio, la curatela iba dirigida a los mayores de 14 años y menores de 25 , o a quienes, siendo mayores de esta edad, estuvieran demenciados y no tuvieran, por tanto, suficiente capacidad para regirse por sí solos.

${ }^{85}$ Vide, LETE DEL RÍO, J.M.: Pasado y presente de la tutela de los menores e incapacitados, en Documentación Juridica, t. XI, enero/marzo 1984, Madrid, p. 21; LACRUZ BERDEJO (J.L), y SANCHO REBULLIDA (F.): Elementos de Derecho Civil, Derecho de Familia, t. IV, Bosch, Barcelona, 1980-1995, p. 276.

${ }^{86}$ LASSO GAITE, J.F. (ob. cit., p. 29): «Las Partidas o Código de las Siete Partidas, es el monumento jurídico más famoso de nuestro derecho y durante seis siglos fuente básica del derecho castellano...Generalmente se atribuye su redacción a Alfonso $\mathrm{X} \ldots{ }^{\prime}$. 
En segundo lugar, las Partidas distinguieron tres tipos de tutela: testamentaria, legítima y dativa; así, «cuando el padre establece guardador á su fijo en su testamento á que llaman en latín tutor testamentarius. Cuando el padre no deja guardador al fijo en su testamento é ha parientes; ca entonce las leyes otorgan que sea guardador del huérfano el más cercano pariente, é este tal de dicho tutor legítimo dado por ley é por derecho. La tercera manera es cuando el padre non deje guardador á su fijo ni ha pariente ó si lo ha es embargado de manera que non lo puede ó non quiere guardar; é entonce el juez de aquel lugar le da por guardador algun home bueno é leal é á este a tal dicen en latín tutor dativus, es decir, guardador dado por albedrío del juez... » (Partida 6 ${ }^{\mathrm{a}}$, título XVI, ley $2^{\mathrm{a}}$ ).

La tutela testamentaria era, por tanto, la ordenada por el padre, la madre $\mathrm{u}$ otra persona que hubiese instituido heredero al huérfano; la legítima, en defecto de la anterior, se defería por ministerio de la ley a los parientes más próximos; y, finalmente, la dativa era la instituida por el Juez para el pupilo en defecto de las dos anteriores.

En las leyes $3 .^{\mathrm{a}} \mathrm{y} 4 .^{\mathrm{a}}$ se determinaba quiénes podían ser tutores, excluyéndose a los «mudos, sordos, desmemoriados, desgastadores de lo que ovieren (pródigos) y a los de malas maneras (costumbres), así como a las mujeres y a los varones menores de veinticinco años». La mujer únicamente podía ser tutora en su calidad de madre o abuela, siempre que no contrajera segundas nupcias; en este caso, su exclusión se debía a la presunción de que el nuevo marido materno no tendría interés alguno en guardar y proteger los bienes del tutelado. De lo expuesto se deduce, que la capacidad exigida para ser tutor era la de hallarse en la plenitud de los derechos civiles y no estar incurso en ninguno de los casos de incapacidad, según las leyes ${ }^{87}$.

Respecto a su ejercicio, la tutela presentaba carácter obligatorio, existiendo una serie de excusas legales, que eran consideradas como «beneficio o privilegio» de la Ley ${ }^{88}$.

${ }^{87}$ Partida $6^{\mathrm{a}}$, título XVI, ley 7. ${ }^{\mathrm{a}}:$ "... Dexando el padre a alguno de sus siervos por guardador de sus fijos, Moguer non le ouiesse ante desto aforrado por palabra, fazese libre por esta razon, e sera guardador dellos, si fuer mayor de veynte e cinco años; e si fuere menor, como quier que sea forro, non sera guardador dellos, fasta que sea de la edad sobredicha. Mas si dexasse sieruo ageno, non valdria, nin seria guardador dellos...».

Partida 6", título XVI, ley 14. ${ }^{\mathrm{a}}$ : "Obispo, nin Monge, nin otro Religioso, non puede ser guardador del huerfano; porque estos atales han de servir a Dios en las Iglesias, e embargarse ya este servicio por la guarda que ouiesse de fazer en las personas, e en los bienes de los huerfanos...».

${ }^{88}$ Partida $6^{\mathrm{a}}$, título XVII, ley $2 .^{\mathrm{a}}$ : "Razones ciertas son, porque los omes se pueden escusar, que non sean guardadores de huerfanos. La primera es, quando aquel que es 
Por lo que se refiere a las obligaciones del tutor, éste ostentaba el deber de educar física, moral e intelectualmente al tutelado ${ }^{89}$, velar por los bienes del pupilo, a cuyo efecto venía obligado a realizar un inventario de los mismos ${ }^{90}$, representarle en juicio y fuera de él compareciendo siempre en su nombre ${ }^{91}$ y evitar la enajenación de cualquiera de los bienes del tutelado ${ }^{92}$. A fin de que se hicieran efectivas dichas obligaciones,

dado por guardador, ha cinco fijos naturales, e legitimos bious. Pero si alguno ouiesse perdido de los cinco fijos vno, o mas, en batalla en seruicio de Dios, e del Rey, bien puede ser contado entre los biuos, e escusarse el padre por esta razón, de ser guardador. Otrosi se pueden escusar, que non sean guardadores, todos aquellos que han de recabdar las rentas del Rey, e los que son mensajeros, e los que han de judgar, e cumplir la justicia por obra. Pero si alguno destos ouiesse recibido en guarda algun huerfano ante que lo ouiessen dado aquel oficio, non se podria después escusar por esta razon, que lo non ouiesse en guarda. Otrosi dezimos, que si algun guardador de huerfanos ouiesse de yr en seruicio del Rey, por su mandado, a alguna parte que fuesse muylueñe; o fuese alla, por seruicio, o por procomunal de la tierra en que biue; este atal deuenle atender, fasta que venga. Pero deue dexar los mocos, e sus bienes en guarda, e en recabdo de tal ome, que piense bien dellos, de mientra que el tornare....E aun dezimos, que auiendo algun ome tres guardas de huerfanos, si acaeciese que le quieran dar otro en guarda, bien se puede escusar por tal razon como esta, que non reciba la quarta guarda. Otrosi, el que fuesse tan pobre, que non ouiesse al, por que guarecer, si non por labor de sus manos, bien se puede escusar que non sea guardador de huerfano. Otro si se podria escusar que non fuesse guardador, el que fuesse enfermo de tal enfermedad, de que nunca pudiesse guarecer. E aun, el que non supiesse leer, nin escreuir, si fuesse tan simple, o tan necio, que non se atreuiesse a fazer la guarda con recabdo. E aun se podria escusar de la guarda del huerfano, el que ouiesse auido grand enemistad capital con el padre de aquel que le quisiesse dar en guarda...o si le ouiesse assechado en otra manera, por lo matar; o si ouiesse seydo su enemigo conocidamente, e non fuesse después fecha paz entre ellos. E escusarse podria otrosi de la guarda, aquel a quien ouiesse mouido pleyto de servidumbre el padre del huerfano o el al otro. E otrosi el que fuesse mayor de setenta años, o menor de veynteecinco".

Partida 6a , título XVII, ley 3. ${ }^{\mathrm{a}}$ : "Caballero que estouiesse en Corte dl Rey, o en otro lugar señalado por mandado del, o por pro comunal de la tierra, bien se puede escusar, que non tome guarda de huerfano, por razon de aquel seruicio que faze. Otrosi el que fuesse Maestro de Gramatica, o de Rhetorica, o de Dialectica, o de Fisica...».

${ }^{89}$ Partida 6 , título XVI, ley 16. ${ }^{\mathrm{a}}$ : "Trabajarse deue el guardador, de fazer al moco que tosiere en guarda, que aprenda buenas maneras; e de si, deuele fazer aprender, leer, e escreuir; e después desto, deuel pon er, que aprenda, e vse aquel menester, que mas le conviniere, según su natura, e la riqueza, e el poder, que ouiere...».

${ }^{90}$ Partida $6^{\mathrm{a}}$, título XVI, ley 15. ${ }^{\mathrm{a}}$ : «...deuden fazer escrito de todos los bienes, de los mocos, con otorgamiento del Juez del logar; e sea fecho por mano de alguno de los Escriuanos publicos...».

${ }^{91}$ Partida 6 a , título XVI, ley 17. ${ }^{\mathrm{a}}$ : "El guardador en nome del huerfano deue demandar, e defender el derecho del entodo pleyto, que mouiesse, o le fuesse mouido en juicio....".

${ }^{92}$ Partida $6^{\mathrm{a}}$, título XVI, ley 18. ${ }^{\mathrm{a}}$ : "Non deuen los guardadores dar, non vender, nin enagenar ninguna de las cosas del huerfano...». 
se aprecia una injerencia muy intensa de la Autoridad Judicial que está presente en toda la normativa y desarrollo de la tutela; así, el inventario debía ser redactado en presencia del juez (Partida 6 ${ }^{\mathrm{a}}$, título XVI, ley 15. ${ }^{\mathrm{a}}$ ) y la fianza aparece también recogida con claro carácter previo y judicial (Partida 6 ${ }^{\text {, }}$ título XVI, ley 9. ${ }^{\text {a }}$ 93. $^{93}$.

Por otro lado, en el Código de Partidas poco se dice sobre los derechos reconocidos al tutor. Se reconoce el derecho a ser reembolsado y restituido en los gastos que haya llevado a cabo a favor del tutelado durante el tiempo que dure su cargo ${ }^{94}$. Según, PESET REIG, «aunque las Partidas nada dice, en virtud de disposiciones del Fuero Real tiene derecho a cobrar una décima parte de las rentas, como retribución de sus tareas ${ }^{95}$.

Se hace presente, pues, en este texto alfonsino el predominio de deberes y obligaciones del tutor frente a los escasos derechos reconocidos al mismo por el ejercicio de su cargo.

La extinción o cese de la tutela, que podía ser total o parcial, se derivaba, entre otras causas, de la muerte del pupilo, de su adopción, por llegar a la edad de la pubertad, por cumplimiento del plazo o condición señalada, por interdicción judicial y civil, por excusa, y, finalmente, por la remoción del tutor ${ }^{96}$.

Se hace precisa una breve referencia a la remoción como sanción impuesta al tutor sospechoso. Tenía lugar, entre otros motivos, por falta de inventario, por resultar enemigo del huérfano o de sus descendientes, por la ocultación del tutor que, sabiendo su nombramiento, no se presentaba a aceptar el cargo, por su falsa manifestación de carecer de alimentos con que atender al pupilo, por la enaje-

93 PALOMINO DÍEZ, I.: La organización de la tutela como tutela de familia o tutela de autoridad: un dilema histórico, en Nuevo Mundo Mundos Nuevos, Coloquios 2008 (URL: http:/nuevomundo.revues.org/23013), p. 4.

${ }^{94}$ Partida $6^{\mathrm{a}}$, título XVI, ley 20. ${ }^{\mathrm{a}}$ : "...Pero si el guardador entendiesse, que seria daño del moco en descubrir la riqueza, o la pobreza del, e por esta razon le gouernasse de los suyo, espediendo por el tanto, quanto fuesse guisado, o poco mas, por esta razon; entonce dezimos, que lo puede fazer, e deuele después el moco quando fuere de edad, pagar todo lo que desta manera ouiesse despendido por el».

${ }^{95}$ PESET REIG, M.: Los antecedentes de la unión de la tutela y la curatela en el Código civil español, en R.C.D.I., enero-febrero 1971, núm. 482, p. 311.

${ }^{96}$ Partida 6", título XVI, ley 21. a: "Durar deue el oficio de los guardadores, fasta que los huerfanos sean de edad de catorze años, si fueren varones; e si fueren mugeres, fasta que sean de doze. Otrosi se acaba tal guarda como esta, por muerte, o por desterramiento del guardador, o del huerfano. Esso mismo seria, si tornasse en servidumbre, o catiuassen a cualquier dellos...». 
nación de bienes sin los requisitos de Derecho, por la indefensión del pupilo en juicio o fuera de él, por haber administrado en fraude el patrimonio de otro pupilo o dirigido de modo inmoral su educación, y, en suma, por cualquier causa que hiciese presumir que su tutela resultaría perjudicial para la persona o los bienes del pupilo ${ }^{97}$.

De todo lo anterior, se infiere que la tutela y la curatela constituyen el régimen tutelar del Derecho inmediatamente anterior al Código civil. Sin embargo, antes de analizar el estado de la institución tutelar en la Codificación civil, pasaremos a estudiar el estado de la legislación y la cultura jurídica anteriores a las tareas codificadoras.

\section{A) PROYECTO DE CÓDIGO CIVIL DE 1821.}

El Proyecto de Código civil de 1821 constituye la primera huella de nuestra codificación civil. Es un Proyecto que recoge cosas del código francés reflejado en pequeños detalles y mejoras, pero sin trasladar a nuestro Derecho su esquema fundamental, es decir, hay una cierta influencia francesa, pero manteniendo el espíritu y estructura de las viejas Partidas.

La Parte Primera del Proyecto contaba con tres Libros; el Libro segundo, bajo el epígrafe «De los derechos y de las obligaciones con respecto à las personas según su diferente condición doméstica» (arts. 277-476), se dividía en cuatro títulos que tratan respectivamente, «De la condición de marido y muger»; «De la condición de padres é hijos»; «De la condición de protector y protegido», $\mathrm{y}$ «De la condición de de superior y dependiente».

El título tercero, que se ocupaba «De la condición de protector y protegido», es el que nos suscita un mayor interés. Siguiendo con la tradición del Código de las Siete Partidas, se continúa con la regulación conjunta de ambas guardas (tutela y curatela).

El artículo 386 definía la tutela como «el encargo de cuidar y proteger las personas y los bienes de los célibes menores de veinte años,

${ }^{97}$ Partida $6^{\mathrm{a}}$, título XVIII, ley 1. ${ }^{\mathrm{a}}$ » Aquel guardador puede ser llamado sospechoso, que es de tales maneras, que pueden sospechar contra el, que desgastara los bienes del huerfano, o que le mostrara malas costumbres. E Moguer este atal fuesse rico, e quisiesse dar fiador, de guardar, e aliñar los bienes del moco, por todo esso non le deuen dexar en su guarda, porque tal fiadora non le toldria al guardador el mal entendimiento, o la mala voluntad que ouiesse, en gastar lo del huerfano...». 
huérfanos de padre y de madre». El Proyecto de Ley no reconoce más que un tutor, "si hubiera muchos nombrados por los padres, o si fueren muchos los parientes llamados a la tutela o curaduría, deben convenirse entre sí para designar la persona que haya de ejercer el encargo; y si no se conviene se hace esta designación por el Alcalde...» (art. 419 Proyecto de C.c. de 1821). No obstante, «cuando el menor ó persona incapacitada tuviere bienes muy cuantiosos en distinta provincia ó en lugares muy distantes dentro de una misma provincia, podrá nombrarse por los padres ó por la Autoridad pública un tutor ó curador particular para la administración de los bienes de un cierto distrito» (art. 420 Proyecto de C.c. de 1821).

Se distinguen dos tipos de tutela, según que se difiriese por voluntad de los padres o por disposición de la ley; es decir, legítima y dativa (art. 387 Proyecto de C.c. de 1821).

Una vez nombrado el tutor por el Alcalde del pueblo, este debía aceptar el cargo expresamente, prestar juramento del fiel desempeño de su cargo y dar caución por medio de fiadores, de modo que garantizasen su buen cumplimiento (art. 414 Proyecto de Código civil de 1821).

Por su parte, la curaduría se definía en el artículo 394 como «el encargo de proteger y cuidar los bienes, y aun las personas en su caso, de los mayores de veinte años huérfanos, y de los mayores de veinte y cinco libres de la potestad patria, cuando unos y otros se hallan incapacitados de administrar sus cosas por algún impedimento físico ó moral». El Proyecto consideraba susceptibles de incapacitación a los locos, a los mentecatos, y a los disipados o pródigos (art. 395 Proyecto de Código civil de 1821).

El Capítulo V de este Libro II contenía, bajo la rúbrica «Del ejercicio de la tutela y curaduría», los derechos y los deberes que se atribuían al tutor y al curador en el ejercicio de su cargo. En concreto, el artículo 423 reconocía las siguientes obligaciones: «1. ${ }^{\circ}$ á cuidar con esmero de la persona del protegido: $2{ }^{\circ}$ á administrar sus cosas con la

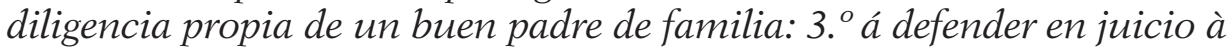
la persona protegida activa y pasivamente». El artículo 425 se refería al deber del tutor de proporcionar la adecuada educación al menor atendiendo a las circunstancias de los mismos. Otra referencia en relación a la buena administración que se debía llevar a cabo de los bienes del protegido se hallaba en el artículo 428 del citado texto legal, a cuyo tenor: «Los tutores y curadores deben administrar los bienes de los protegidos del mejor modo posible, según su clase y naturaleza, empleando provechosamente los caudales que no tuvieren un destino preci- 
so». Una vez expirado el cargo de tutor, éste tenía la obligación de rendir cuentas de su administración (arts. 451, 452 Proyecto de Código civil de 1821).

Por otro lado, en este Proyecto de Codificación encontramos también regulados los derechos del tutor y del curador. Así, el artículo 424 apuntaba que «El tutor tiene derecho á ser obedecido y respetado por el menor. Puede á este fin usar de los consejos y de la corrección módica; y no surtiendo efecto, interpelar la autoridad pública...». El artículo 449, por su parte, exponía el derecho del tutor a percibir una indemnización «de las cantidades que hayan anticipado á beneficio de la persona protegida...».

El derecho a la remuneración del tutor constituye una aportación del Fuero Juzgo y Fuero Real, destinaban a tal fin una décima parte de las rentas anuales. Sin embargo, el Proyecto de 1821 concretaba en su artículo 454 «una cuota determinada anual con proporción á las facultades de la persona protegida, que no exceda del diez, ni baje del cuatro por ciento del producto de los bienes inmuebles y réditos que se recaudan.

Esta cuota será determinada por el Alcalde en unión con el Regidor y el Procurador síndico mas antiguos del pueblo, y se satisfará del haber de la persona protegida».

Existían en el mencionado Proyecto preceptos referidos a las causas de excusa que o exoneración de la tutela y la curaduría (arts. 402-413), así como a los motivos o causas que motivaran la cesación del cargo de tutor o curador (arts. 438-454).

En definitiva, la característica externa y formal más notable de este Proyecto, es la utilización de una estructura y un plan absolutamente nuevos en la historia del Derecho español. Su gran mérito radica, sin duda, en haber servido de estímulo para el inicio de la labor codificadora en nuestro país ${ }^{98}$.

\section{B) PROYECTO DE CÓDIGO CIVIL DE 1836.}

El Proyecto de Código Civil de 1836 supuso un paso adelante en la Codificación de nuestro Derecho Civil. Se trata del primer Proyecto de Código civil que se redacta completo en la larga historia de nuestra

98 BARÓ PAZOS, J.: La codificación del Derecho civil en España (1808-1889), Universidad de Cantabria, Cantabria, 1992, pp. 61, 63 y 64. 
LA PROTECCIÓN JURÍDICO-PATRIMONIAL DEL MENOR Y DEL INCAPACITADO ...

Codificación. Este Proyecto coincide en su contenido y estructura con los objetivos propios de un Código civil; esto es, se limita estrictamente a las materias de derecho privado ${ }^{99}$. Consta de un Título Preliminar, y de cuatro Libros, con un total de 2.458 artículos. El Libro I, «De las personas» dedicaba a los regímenes de guarda su Título XIII, «Sobre la tutela y curaduría», que comprendía trece capítulos (112 artículos).

El artículo 433 definía la tutela como «Cargo civil que se confiere a sujeto idóneo para cuidar y defender la persona y los bienes de los huérfanos de padre y madre que se hallen en la edad pupilar» (varones y hembras menores de catorce años).

Siguiendo el Derecho romano, este Proyecto suprimió el Consejo de Familia y distinguió entre la tutela y la curaduría.

Al igual que en el Derecho romano, la institución de la tutela se dirigía a la guarda de los que no hubieran alcanzado la pubertad, es decir, a los varones huérfanos menores de catorce años, y a las hembras menores de doce; desde esta edad hasta los veinticinco cumplidos, en que empezaba la mayor edad, se les asignaban curadores.

La curaduría se definía en su artículo 437 como «el cargo de defender y cuidar los bienes y la persona de los huérfanos de ambos sexos mayores de catorce años hasta los veinticinco, o de los que hallándose en la mayor edad tuvieran imposibilidad física o moral de administrar sus bienes y defender personalmente sus derechos».

Como novedad, este proyecto admitía la figura del curador especial, nombrado ad hoc por la autoridad judicial para la defensa y cuidado de determinados bienes del huérfano vinculados a ciertos negocios, no pudiendo intervenir en aquéllos para los que no hubiese sido especialmente habilitado ${ }^{100}$.

\section{C) PROYECTO DE CÓDIGO CIVIL DE 1851.}

El Proyecto de Código civil de 1851 marca un hito en el proceso de la Codificación del Derecho civil de nuestro país. Sin embargo, debe ser considerado como un eslabón más, aunque decisivo y prácticamente concluyente, del proceso de la Codificación de nuestro

${ }^{99}$ BARÓ PAZOS, J.: ob. cit., p. 69.

${ }^{100}$ BARÓ PAZOS, J.: ob. cit., p. 77. 
Derecho Civil, que culmina con la redacción del Código Civil de 1889.

Este Proyecto isabelino constaba de cuatro Libros; el Libro I, bajo la rúbrica "De las personas», contaba con 452 artículos que dividías en 10 Títulos. Dado nuestro tema de estudio, abordaremos, a continuación, los Títulos VII y IX, referidos a «tutela» y «curaduría de los mayores de edad inhábiles para administrar sus bienes» respectivamente.

El artículo 172 preceptuaba que la tutela debía ejercerse por el tutor de modo inexcusable, bajo la vigilancia del protutor y del Consejo de familia. La introducción de la figura del protutor hace innecesaria la del curador especial que en el Derecho Romano, en las Partidas e incluso en el Proyecto de Codificación de 1821 se nombraba al menor en caso de conflicto de intereses con los del tutor. Por otro lado, la figura del Consejo de familia servía de garantía para el huérfano, en cuanto permitía que el tutor estuviese vigilado por sus parientes más próximos ${ }^{101}$.

Tanto el protutor como el Consejo de familia constituían aspectos novedosos en nuestro Derecho tradicional, que denotaban la influencia del Código civil francés ${ }^{102}$. En este sentido, en la elaboración del Proyecto de Código Civil de 1851 no sólo se optó por la unificación de los cargos de tutor y curador, sino que, a imitación del Código civil galo, se adoptaron en nuestro sistema las figuras del protutor y del Consejo de familia ${ }^{103}$.

El tutor tenía la obligación de administrar el patrimonio del tutelado, alimentarlo y educarlo conforme a su clase y fortuna, fijando el Consejo de familia estos extremos, así como el destino que debía darse al sobrante de sus rentas. Los actos de enajenación y gravamen de inmuebles requerían detallado y especial permiso del Consejo. Pesaba también sobre el tutor la obligación de rendir cuentas en el plazo de dos

${ }^{101}$ BARÓ PAZOS, J.: ob. cit., p. 121.

${ }^{102}$ A juicio de PLANIOL, M. (Traité élémentaire de Droit civil conforme au programme officiel des facultés de droit, 10. ${ }^{\text {a }}$ ed., t. I, Paris, 1925, p. 567) la tutela en Francia consiste en un mecanismo con tres ruedas: el «consejo de familia» primero, en el que descansa la potencia tutelar; en segundo término, el «tutor», que obra; y después el llamado «subrogé tuteaur» que vigila a aquél y le reemplaza en caso necesario. La tutela constituye, pues, algo así como un pequeño gobierno que tiene su asamblea deliberante, su poder ejecutivo y hasta su censor. Algo parecido ocurría en España (hasta la reforma en materia de tutela operada por la ley 13/1983, 24 de octubre, de reforma del Código Civil en materia de Tutela), donde existía: el Consejo de familia como autoridad superior que decidía sobre las cuestiones que se suscitaban; el tutor, que ejecutaba los acuerdos tomados por aquél, y el protutor, que fiscalizaba los actos de éste.

${ }^{103}$ Dichas figuras desaparecidas tras la entrada en vigor de la Ley 13/1983, 24 de octubre, de reforma del Código Civil en materia de tutela. 
meses desde el término de la tutela. El protutor debía darlas anualmente elevándolas al Consejo de familia en el caso de detectar alguna irregularidad. Por su parte, el derecho a una cierta remuneración por el ejercicio de su cargo representa una aportación del Fuero Juzgo y del Fuero Real, fijándose en un 8 por 100 por los padres en el testamento, y en su defecto, por el Consejo de familia ${ }^{104}$.

El Título IX se refería a la curaduría. A tenor del artículo 278 del Proyecto, «Se da curador al mayor de edad capaz de administrar sus bienes por sí mismo. Son incapaces de administrar sus bienes el mentecato, el loco o furioso habitual aunque tenga lúcidos intervalos, el sordomudo que no sabe leer ni escribir, el pródigo y el que está sufriendo la interdicción civil». De este modo, el Proyecto descartaba la curaduría de los menores.

Por tanto, venimos observando como el movimiento codificador apunta un cambio de rumbo en la institución tutelar, marcando las bases para la supresión de la dualidad tutela y curatela. Ligeros atisbos de este intento unificador se observan en el Proyecto de 1821, pero será el Proyecto de 1851 el que dé el primer paso aunque todavía mantenga la distinción ${ }^{105}$.

En definitiva, en este Proyecto isabelino, prácticamente todas las instituciones que son propias del Código civil aparecían reguladas en su completo articulado, a lo largo de sus 1.992 artículos. Nos encontramos, pues, ante un Proyecto de una calidad indiscutible, aunque, como toda obra humana, no se encontraba exento de errores y defectos ${ }^{106}$.

\section{D) LEY DE ENJUICIAMIENTO CIVIL DE 3 DE FEBRERO DE 1881.}

La Ley de Enjuiciamiento Civil de 3 de febrero de 1881 regulaba en su Libro III, Título III, Sección Primera, el nombramiento de tutores y curadores, bajo la rúbrica «Del nombramiento de tutores y curadores y del discernimiento de estos cargos».

El nombramiento del tutor se llevaba a cabo mediante disposición testamentaria del padre, de la madre o de cualquier otra persona que hubiere instituido heredero al menor ${ }^{107}$. En el supuesto de que

${ }^{104}$ PESET REIG, M.: ob. cit., p. 332 y ss.

${ }^{105}$ LETE DEL RÍO, J.M.: ob. cit., p. 22.

${ }^{106}$ BARÓ PAZOS, J.: ob. cit., pp. 134 y 135.

107 Artículo 1.833 LEC: «Acreditado el nombramiento del tutor, hecho en disposición testamentaria por el padre o la madre del menor, mandará el Juez que se le discierna el cargo sin exigirle fianzas, si se le hubiere relevado de darlas». 
ninguno de los anteriormente citados hubiese nombrado un tutor, el Juez designaba para el cargo al pariente que, según la ley, le correspondiera. A falta de pariente, o en el caso de existir pero no reunir las condiciones necesarias, el juez nombraba a una persona que considerase de su confianza ${ }^{108}$.

Para el adecuado desempeño del cargo, se establecía como necesaria la aceptación del designado. Si el tutor se oponía al nombramiento, se oía al Ministerio Fiscal y, si daba el visto bueno, el Juez procedía al nombramiento de un nuevo tutor. En el caso de no estar conforme, quedaba en manos del Juez la decisión final, quien siempre debía tener en cuenta el interés del menor ${ }^{109}$.

En cuanto al contenido del cargo de tutor, el citado texto legal señala la obligación de prestar fianza, siempre y cuando se den razones fundadas que lleven al Juez a adoptar tal decisión ${ }^{110}$. Sin embargo, nada se dice acerca de los derechos que corresponden al tutor por el desempeño de sus funciones.

La Ley de Enjuiciamiento Civil de 3 de febrero de 1881, contiene también la regulación del nombramiento de curador. No habiendo curador nombrado, corresponderá al mismo menor su

Artículo 1.834 LEC: «También se mandará discernir el cargo de tutor al nombrado por cualquier persona que haya instituido heredero al menor, o dejándole manda o legado de importancia...».

${ }^{108}$ Artículos 1.836 LEC: "No habiendo tutor nombrado por el padre, la madre u otra persona que haya instituido heredero al menor, o dejándole manda de importancia, designará el Juez para este cargo al pariente a quien corresponda con arreglo a la Ley».

Artículo 1.838 LEC: «A falta de pariente a quien designar, o no reuniendo el que hubiere las cualidades que exigen las leyes, lo cual se hará constar en el expediente, el Juez. nombrará para el desempeño del cargo a la persona que merezca su confianza».

${ }^{109}$ Artículos 1.837 LEC: «Previa la aceptación del designado y la prestación de fianza, en su caso, se le discernirá el cargo».

Artículo 1.839 LEC: «Si se hiciere oposición al nombramiento, se discutirá y resolverá por los trámites de los incidentes entre el que la promueva y el tutor nombrado, representando los intereses del menor el Ministerio Fiscal...».

Artículo 1.840 LEC: "Oponiéndose el tutor elegido a aceptar el cargo, se oirá al Ministerio Fiscal; y si éste está conforme, nombrará el Juez nuevo tutor.

Si el Ministerior Fiscal no se conformare, se discutirá y resolverá la oposición por los trámites de los incidentes, observándose lo prevenido en el párrafo segundo del artículo anterior».

${ }^{110}$ Artículo 1.835 LEC: «No obstante lo dispuesto en los dos artículos anteriores, cuando sobrevengan razones muy fundadas, que el Juez apreciará atendidas las circunstancias especiales que en su caso concurran, podrá exigir la prestación de fianza aun al tutor o curador nombrado por el padre o la madre, o por otra persona que haya dejado al menor manda o legado de importancia». 
LA PROTECCIÓN JURÍDICO-PATRIMONIAL DEL MENOR Y DEL INCAPACITADO ...

nombramiento (art. 1844 LEC); pero si el nombrado curador no reuniese las condiciones necesarias para el desempeño del cargo, podrá el juez negarse invitando al menor a que nombre otro (art. 1846 LEC).

En definitiva, la Codificación del Derecho civil en nuestro país ha de ser considerada globalmente como el resultado final de un largo proceso, en el que todos los proyectos, incluso los de iniciativa particular, y los elaborados bajo el prisma de una u otra ideología, aportan, en mayor o menor grado, su cuota de participación en la conclusión de la Codificación ${ }^{111}$.

\section{E) LA REGULACIÓN INICIAL DEL CÓDIGO CIVIL DE 1889.}

La regulación primitiva de la tutela en la redacción inicial del Código Civil de 1889 intentó seguir el esquema fundamental del Proyecto de 1851 y las directrices del Código civil francés y otros europeos. Esto se percibe en el marcado carácter familiar de la tutela en la que un órgano integrado fundamentalmente por parientes del pupilo, como es el Consejo de familia, se convierte en el principal eje del organismo tutelar, sin olvidar en ciertas ocasiones la intervención del Juez $^{112}$. En este sentido, el artículo 201 del Código civil delimita los órganos que integran el organismo tutelar; así, «La tutela se ejercerá por un solo tutor bajo la vigilancia del Protutor y del Consejo de familia» ${ }^{113}$.

En la regulación primitiva de nuestro Código civil no se recoge una definición propia de tutela, pero en uno de sus preceptos, concretamente el 199, se regulaba el objeto de aquélla en los siguientes términos: "El objeto de la tutela es la guarda de la persona y bienes, o solamente de los bienes, de los que no estando bajo la patria potestad, son incapaces de gobernarse por sí mismos».

El ámbito de la tutela quedó modificado en virtud del principio de unificación de la guarda legal. El Código quiso refundir las antiguas

${ }^{111}$ BARÓ PAZOS, J.: ob. cit., p. 102.

${ }^{112}$ En la STS de 5 de marzo de 1947, leemos que: «... la intervención judicial en materia de tutela reviste un carácter activo, pudiendo ser ejercitada por iniciativa propia sin que en su actuación "ad tuendum» se hallen los Tribunales subordinados necesariamente a la solicitud de parte».Vide también la STS de 17 de junio de 1943.

Sigue esta misma doctrina CASTÁN TOBENAS, J.: ob. cit., pp. 510 y 511; LETE DEL RÍO, J.M.: ob. cit., pp. 28 y 29.

${ }^{113}$ PALOMINO DÍEZ, I.: ob. cit., pp. 5 y 6. 
instituciones pupilares, por entender que era artificial la distinción romana de la tutela y la curatela ${ }^{114}$.

Estaban sujetos a la tutela los menores de edad no emancipados legalmente, los locos o dementes aunque tuvieran intervalos lúcidos, los sordomudos que no supieran leer ni escribir, los que por sentencia firme hubieren sido declarados pródigos, y los que estuvieran sufriendo la pena de interdicción civil (art. 200 C.c.). El artículo 203 del Código establecía que los Jueces municipales del lugar en que residieran las personas sujetas a la tutela eran los encargados de protegerles hasta que se les nombrara tutor. Por tanto, el sistema de familia no estaba presente en su estado puro, ya que la autoridad judicial contaba con facultades y poderes de relevancia que, si bien eran llevados a la práctica, estaban definidos de forma poco precisa en el ordenamiento ${ }^{115}$.

La tutela de los menores se atribuía a los abuelos, con preferencia de los paternos; en segundo lugar y con la misma preferencia, a las abuelas; en defecto de éstos, al mayor de los hermanos varones de doble vínculo, y, a falta de éstos, al mayor de los hermanos consanguíneos o uterinos (art. 211 C.c.).

En cuanto a los locos y a los sordomudos, debía primeramente precederles una declaración de incapacidad, que podía ser instada por el cónyuge o por los parientes que habían de sucederle $a b$ intestato (art. 214 C.c.).

Las diversas maneras de delación de la tutela poco distan de los tiempos del Derecho romano; si en estos eran fundamentos de dela-

${ }^{114}$ Es muy ilustrativa, en este sentido, la STS de 6 de febrero de 1968: «aunque la dualidad, tutela y curatela que se da en el Derecho romano y en nuestro Derecho histórico, desaparece en nuestro Código Civil, que, inspirado en el francés, refunde las instituciones tutelares bajo un solo nombre de tutela, subsiste una gran variedad de matices dentro de ella, pues mientras en unos casos se encaminaba fundamentalmente a la guarda de la persona y bienes (menores, locos y sordomudos), en otros se instituye para la administración de los bienes (la de los sujetos a interdicción, la de los pródigos) y en otros muchos sólo se suple la capacidad para actos muy concretos y determinados...».

Véase también CASTÁN TOBEÑAS, J.: ob. cit., p. 408.

${ }^{115}$ Véanse, entre otros, CASTÁN VAZQUEZ, J.M ${ }^{\mathrm{a}}$ : La intervención judicial en la tutela, en A.D.C., 1958, pp. 513 y 514; LETE DEL RÍO: ob. cit., p. 29; y GONZÁLEZALEGRE, M. (Teoría de la tutela y formularios de su práctica, Teruel, 1956, pp. 176 y 177): «El sistema de familia adoptado por nuestros legisladores no plasmó más que en la letra de algunos artículos del Código, pues al ir desarrollando la materia, aquéllos acudieron insensiblemente a la autoridad judicial, a la que fueron atribuyendo funciones importantísimas». 
ción el testamento, la ley y el nombramiento que hiciera el magistrado, el artículo 204 del Código civil estableció, en este mismo sentido, que la tutela quedaba deferida por testamento, por la ley y por el Consejo de familia.

En cuanto a sus elementos y contenido se contempla una modificación en virtud del sistema de tutela orgánica. El Código reguló la tutela como un órgano integrado por diversos elementos. Así, en el Derecho anterior, la tutela se componía simplemente de tutor y de la Autoridad judicial, mientras que en el sistema introducido por el Código civil de 1889 el organismo tutelar quedaba integrado por: tutor, protutor, Consejo de familia y cierta intervención de la autoridad judicial ${ }^{116}$.

La institución del protutor, tomada del Derecho francés, constituye una auténtica novedad en nuestro Derecho Histórico, mientras que el Consejo de familia (que ya acogió el proyecto de 1851) dio lugar a una ardua polémica doctrinal acerca de sus precedentes en nuestro Ordenamiento ${ }^{117}$.

El protutor era un cargo obligatorio (art. 202 C.c.) y gratuito, lo que incidió en su falta de funcionamiento y eficacia en la mayor parte de las ocasiones.

Por su lado, el Consejo de familia encontraba su regulación a lo largo de todo el título X del Libro I. Este órgano se componía por un mínimo de cinco miembros o vocales designados por el padre o la madre en su testamento, por la ley, o por el Juez (art. 294 C.c.). Eran de su competencia todas las decisiones importantes que atañían a la persona o a los bienes del tutelado, debiendo el tutor solicitar su autorización para llevar a cabo los actos más relevantes de la gestión tutelar, lo que está en directa relación con el escaso margen de autonomía que, teóricamente, deja el Código civil a la actuación del tutor ${ }^{118}$.

En definitiva y a la vista de cuanto antecede, a modo de resumen de forma que resulte más fácil su comprensión, la institución tutelar tras la redacción del Código civil de 1889 denota como notas características: en primer lugar, su naturaleza de institución supletoria de la patria potestad, le sigue su sentido orgánico (tutor, protutor y Consejo de familia) y finalmente, el principio de unidad de guarda legal refundiendo en una, tutela y curatela.

${ }^{116}$ Vide CASTAN TOBEÑAS, J.: ob. cit., pp. 409 y 410.

${ }^{117}$ G. CAMINERO, E.: Tratado teórico y práctico sobre Partición de Herencia, Tutela, Protutela y Consejo de Familia, $2^{\text {a }}$ ed., Fernando Fé, Madrid, 1899, pp. 52 y ss.

${ }_{118}$ PALOMINO DIEZ, I.: ob. cit., p. 7. 


\section{F) REFORMAS INTRODUCIDAS POR LA LEY DE 24 DE ABRIL DE 1958.}

La Ley de 24 de abril de 1958 introduce una serie de modificaciones al Código Civil de 1889 que afectan principalmente al régimen del matrimonio. Sin embargo, el régimen tutelar sufre también algunas variaciones en su articulado (arts. 206, 209, 211, 220, 237 y 244) que trataremos de resumir con brevedad.

La redacción inicial del artículo 206 del Código civil reconocía al padre y a la madre la facultad de nombrar tutor para sus hijos, pero si la madre «hubiere contraído segundas nupcias, el nombramiento que hiciere para los hijos de su primer matrimonio no surtirá efecto sin la aprobación del consejo de familia». Sin embargo, la redacción del precepto tras la modificación introducida por la Ley de 24 de abril de 1958, suprime la necesidad de aprobación del Consejo de familia en el caso de que la madre hubiere contraído segundas nupcias.

Por su parte, el artículo 209 del Código civil permanece prácticamente inalterado excepto en el apartado $1^{\circ}$, en el caso de que hayan sido nombrados varios tutores, se optará como primera opción por el «elegido por el padre o la madre» y tras la redacción de la Ley de 24 de abril de 1958 se sigue manteniendo como primera alternativa al designado por los padres pero se añade «que hubiere ejercido últimamente la patria potestad». De este modo, en caso de discrepancia en la decisión de un tutor por parte de uno u otro progenitor, se atenderá al deseo del que venga ejerciendo la patria potestad.

El artículo 211 del Código civil hace referencia a la tutela legítima de los menores no emancipados. Este precepto sufre una breve variación respecto a su redacción inicial al añadirse, como última opción, que la tutela corresponda "A las hermanas..." mientras que anteriormente no se hacia referencia a las mismas.

Por su parte, el precepto 220 hace alusión a quien corresponde la tutela de los locos y los sordomudos. En el apartado $3^{\circ}$ se observa que frente a la redacción original que la tutela correspondía a "Los hijos», tras la reforma corresponde "A los hijos, con la preferencia del legítimo sobre el natural, del varón sobre la mujer y del mayor sobre el menor». Por otro lado, la nueva redacción del precepto remite como $4^{\mathrm{a}}$ opción "A las personas señaladas en el artículo 211 ».

Continuando con las variaciones introducidas por la citada Ley, el artículo 237 de la inicial redacción del Código civil eximía de la posibilidad de ser tutor a " $7^{\circ}$ Las mujeres, salvo los casos en que la ley las 
LA PROTECCIÓN JURÍDICO-PATRIMONIAL DEL MENOR Y DEL INCAPACITADO ...

llame expresamente» mientras que La Ley de 24 de abril de 1958 modifica el precepto por «Las mujeres casadas que no hubieren obtenido licencia de su marido». El resto permanece inalterado.

Finalmente, el artículo 244 hace referencia a los sujetos que pueden excusarse del ejercicio de la tutela, introduciéndose como novedad interesante, tras las modificaciones introducidas por la citada Ley, la posibilidad de que las mujeres puedan excusarse de la tutela y la protutela.

\section{G) LA LEY 13/1983, 24 DE OCTUBRE, DE REFORMA DEL CÓDIGO CIVIL EN MATERIA DE TUTELA.}

Después de algunos proyectos privados dirigidos a la reforma de las normas reguladoras de la tutela en el Código civil ${ }^{119}$, se iniciaron en 1978 trabajos prelegislativos oficiales. El Proyecto de Ley presentado a las Cortes Generales en 1983, tras ser discutido por el Congreso y el Senado, acabó convirtiéndose en la Ley 13/1983, de 24 de octubre, de reforma del Código civil en materia de tutela, publicada en el Boletín Oficial del Estado número 256, de 26 de octubre.

Esta Ley modificó profundamente la redacción originaria del Código civil, estableciendo una regulación más acorde con los tiempos actuales. A tal fin, dio una nueva redacción a los títulos IX y X del Libro I del Código civil. El Título IX trata hoy «De la incapacitación» y comprende los nuevos artículos 199 a $214^{120}$. El Título X trata «De la tutela, de la curatela y de la guarda de los menores o incapacitados», $\mathrm{y}$ abarca los artículos 215 a 306 del Código civil.

La nueva regulación española de la tutela tras las reformas llevadas a cabo en la citada ley vienen recogidas en la Exposición de Motivos del Proyecto de Ley de 1983 que puso de relieve que su sistema

${ }^{119}$ En esta línea se pronuncia CASTÁN TOBEÑAS, J. (ob. cit., p 412) que apunta como tales, los trabajos efectuados por don Pedro Apalátegui para la Comisión General de Codificación en la década de los años cincuenta, así como más tarde el Anteproyecto de reforma parcial (para la tutela de los subnormales) elaborado en la Facultad de Derecho de San Sebastián por los profesores Gabriel García Cantero, Juan Cadalso Palau, Javier Hualde Sánchez y Jacinto Gil Rodríguez. Un Proyecto posterior y de gran importancia en al génesisi de la reforma ha sido el contenido en Estudio para la Reforma de los preceptos del Código civil relativos a la tutela, redactado en 1977 en la Universidad Autónoma de Madrid por los profesores Luis Díez-Picazo, Rodríguez, Bercovitz, Carlos Rogel, Antonio Cabanillas y Jorge Camarena y publicado por la Fundación General Mediterránea y la Dirección General de Servicios Sociales.

${ }^{120}$ Actualmente, los artículos 202 a 214 han sido abrogados por la Disposición derogatoria de la ley 1/2000, de 7 de enero, de Enjuiciamiento Civil. 
se basa "sobre principios opuestos a los del anterior» y de que «dos son fundamentalmente los nuevos: el principio de la pluralidad de guarda legal que, junto a la tutela, introduce la curatela (recuperando una institución de larga tradición jurídica) y la figura del defensor judicial; y el principio de la tutela de autoridad, que suprime al Consejo de familia y dota al Juez de amplias facultades, situándolo como pieza fundamental decisoria» ${ }^{121}$.

Por consiguiente, es necesario exponer las novedades y modificaciones más significativas de la Ley de 24 de octubre de 1983 respecto de la legislación anterior; así:

1. Pluralidad de regímenes de guarda legal. Se introduce la curatela como nuevo órgano tuitivo de la persona reestableciéndose, con ello, una parte de nuestra tradición jurídica. Efectivamente, la curatela no es una institución nueva ya que como hemos visto hasta la promulgación del Código civil, la tutela y la curatela velaban por la protección de los menores e incapacitados ${ }^{122}$. En este sentido, el artículo 215 señala que «La guarda y protección de la persona y bienes o solamente de la persona o de los bienes de los menores o incapacitados se realizará, en los casos que proceda, mediante $1 .^{\circ}$ La tutela. 2. ${ }^{\circ}$ La curatela. 3. $^{\circ}$ El defensor judicial».

2- Abandono de raíz del sistema de tutela de familia (tutor, protutor y Consejo de familia) ${ }^{123}$, adscribiendo los órganos tuitivos de

${ }^{121}$ Proyecto de Ley de Reforma del Código civil en materia de tutela, en Boletín Oficial de las Cortes Generales. Congreso de los Diputados, 27 de enero de 1983, p. 12.

${ }^{122}$ GUILARTE MARTÍN-CALERO, C. (La curatela en el nuevo sistema de capacidad graduable, McGraw-Hill, Madrid, 1997, p. 3): «La curatela regulada hoy tiene unos perfiles bien diferenciados de aquella curatela histórica, pues hoy tutela y curatela, más que separarse por los sujetos sometidos a una y a otra como sucedía en el derecho histórico, se diferencian por la función que están llamados a ejercer los tutores y curadores por razón de una y otra; entonces, el curador era el representante y administrador de los bienes, ejerciendo una función análoga a la del tutor, hoy el curador tiene una función asistencial más limitada en la que en ningún caso cabe la representación y administración de los bienes del pupilo»; y VENTOSO ESCRIBANO ( $\mathrm{La}$ reforma de la Tutela, Colex, Madrid, 1985, p. 14): «La dualidad venía recogida por el derecho romano, en dónde se sometía a tutela al impúber y a la mujer y la función típica del tutor consistía en la auctoritas interpositio, aunque a veces también llevase consigo la gestión del patrimonio pupilar. Sin embargo, el objeto de la curatela era la gestión o administración del patrimonio del incapaz...».

${ }^{123}$ Sistema que hasta el momento se había venido superponiendo al sistema de la autoridad, como se pone de manifiesto en la RDGRN de 3 de mayo de 1946, donde se afirma que era indiscutible que la guarda de las personas y bienes de los que, no estando bajo la patria potestad, son incapaces de gobernarse por sí mismos ha sufrido en el Código civil una transformación radical que, restringiendo la intervención del Estado y de las autoridades judiciales en las funciones tutelares, ha buscado el prin- 
la persona a la autoridad o control del Juez ${ }^{124}$. Eran muchos los problemas que planteaba este sistema de autoridad, ya que las deficiencias de la Administración de Justicia siempre han sido una constante en España.

En un principio, se puso en tela de juicio la viabilidad de este sistema judicial, y tras más de 25 años de aplicación del sistema de autoridad, se puede confirmar lo que algún día fue sospecha, es decir, que la falta de medios, la lentitud y el exceso de trabajo de nuestros juzgados ha creado más problemas, en vez de solventarlos ${ }^{125}$.

Hoy resulta fácil encontrar numerosos casos que, debido a su sobrecarga y falta de medios, no pueden ser debidamente atendidos por nuestros juzgados, con la gravedad que comporta que el menor o el incapacitado se vea privado de las atenciones y cuidados judiciales cuando más lo necesitan. Como suele ocurrir, es la familia la que en la mayoría de los casos les cuida y se ocupa de su bienestar hasta que los Tribunales de Justicia acaban decidiendo lo procedente.

Por lo tanto, deberíamos tener en consideración que no existen sistemas tutelares con ventajas absolutas. Ninguno de ellos ofrece una solución definitiva y perdurable. Se trata de buscar cuál sea el más viable y el que mejor se adapte a un contexto determinado.

cipal apoyo de la institución en el elemento familiar. Este sistema de familia venía también recogido en el antiguo artículo 201 del Código civil, conforme al cual «La tutela se ejercerá por un solo tutor bajo la vigilancia del Protutor y del Consejo de Familia».

${ }^{124}$ La STS de 22 de julio de 1993, relativa a la ampliación de la intervención judicial en beneficio del incapacitado, declara que: «...conocida es la ampliación que, en relación con la facultad del órgano jurisdiccional en la institución tutelar, ha supuesto la última reforma operada en el título correspondiente del Código civil, orientándose la nueva regulación en un aumento de la intervención judicial en beneficio del declarado incapaz...». Vide también el AAP de Barcelona de 23 de enero de 1995 y el Proyecto de Ley de reforma del Código civil en materia de tutela, en BOCG, Congreso de Diputados, de 27 de enero de 1983, p. 12.

${ }_{125}$ Palabras pronunciadas por la Senadora Sra. Sauquillo Pérez del Amo, (en la presentación ante la Sesión del Pleno del Senado celebrada el 21 de septiembre de 1983, del dictamen de la Comisión de la Cámara sobre el Proyecto de Ley de Modificación de los Títulos IX y X del Libro I del Código Civil, en el «Diario de Sesiones del Senado» núm. 28, año 1983, II Legislatura, pp. 1404 y 1405) quien apunta que muchos pensarían que es difícil el control y vigilancia judicial en relación a la tutela conociendo lo saturados que están los Tribunales de Justicia, «sin embargo no pueden ser obstáculo que nos impida crear una nueva Ley que signifique el control absoluto del organismo judicial con respecto a la tutela...». 
3. La Ley 13/1983, de 24 de octubre excluye la enumeración taxativa de las causas de incapacitación, identificándose de forma genérica con «las enfermedades o deficiencias persistentes de carácter físico o psíquico que impidan a la persona gobernarse por sí misma» $(\text { art. } 200 \text { C.c. })^{126}$.

4. Permite incluso incapacitar a los menores de edad, cuando se prevea razonablemente que la causa de incapacitación persistirá después de la mayoría de edad ${ }^{127}$. En tal caso, alcanzada la mayoría de edad por el incapacitado, éste quedará sometido a la patria potestad prorrogada, y, cuando ella resulte imposible, a la tutela o curatela según proceda ${ }^{128}$. Repárese en que, si bien ésta es una pretensión reclamada ya desde antaño, no es hasta la reforma operada por la Ley 13/1983, de 24 de octubre, cuando se puede proceder a la incapacitación durante la minoridad, siempre que se prevea que, una vez alcanzada la mayoría de edad la enfermedad seguirá impidiendo al interesado su autogobierno. Se trata, pues, de una incapacitación que sólo puede ser solicitada por los titulares de la patria potestad ${ }^{129}$.

5. Posibilidad de designar al tutor en documento público notarial, distinto del testamento, con lo cuál se refuerza su naturaleza de acto «inter vivos». Por tanto el padre y la madre podrán hacer este nombramiento en cualquier forma de testamento, en escritura pública, pero no en acta pública notarial ${ }^{130}$. Así, las escrituras públicas «tienen como contenido propio las declaraciones e voluntad y los actos jurídicos que impliquen prestación de consentimiento...» (art.

${ }^{126}$ En el mismo sentido, las SSTS de 10 febrero de 1986; 28 junio de 1990; 31 diciembre de 1991; 31 octubre de 1994; 19 febrero de 1996; 19 mayo de 1998; 28 julio de 1998: «Para que se incapacite a una persona...lo que verdaderamente sobresale es, que el trastorno, tanto sea permanente como oscile en intensidad, impida gobernarse a la afectada por sí misma...»; la STS de 20 noviembre de 2002: «El presupuesto de la persistencia de la enfermedad o deficiencia del incapacitado esta exigido por la Ley...»; y la STS de 11 junio de 2004.

127 Artículo 201 C.c.: "Los menores de edad podrán ser incapacitados cuando concurra en ellos causa de incapacitación y se prevea razonablemente que la misma persistirá después de la mayoría de edad».

${ }_{128}$ Artículo 171 C.c.: "La patria potestad sobre los hijos que hubieren sido incapacitados quedará prorrogada, por ministerio de la Ley, al llegar aquéllos a la mayor edad...Si al cesar la patria potestad prorrogada subsistiere el estado de incapacitación, se constituirá la tutela o curatela, según proceda».

${ }^{129}$ Artículo 757.4 LEC: «...la incapacitación de menores de edad en los casos en que proceda conforme la Ley, sólo podrá ser promovida por quienes ejerzan la patria potestad o tutela».

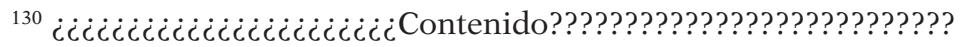


144.2 RN) mientras que las actas notariales «tienen como contenido la constatación de los hechos o la percepción que de los mismos tenga el notario, siempre que por su indole no puedan calificarse de actos y contratos, así como sus juicios o calificaciones». (art. 144.4 $\mathrm{RN}$ ). Por ello, la designación de tutor puede llevarse a cabo en escritura pública notarial pero nunca en acta pública notarial.

6. Heterogénea variedad de posibilidades de tutela (tutela plena, restringida; tutela de la persona, de los bienes; tutela ejercida por persona física, por persona jurídica o por el Director del establecimiento público, etc).

7. La prodigalidad ya no es una causa de incapacitación, pero sí de sometimiento a la curatela del declarado pródigo. Su fundamento reside en la protección del derecho a alimentos de los herederos legitimarios (cónyuge, descendientes o ascendientes) (arts. 294 y 807 del C.c.).

8. Se regula la guarda de hecho con normas breves que dan solución a cuestiones que se plantean en la vida real.

Vistas hasta ahora las principales novedades introducidas por la Ley de reforma de 24 de octubre de 1983, nos interesaría a continuación apuntar la concepción de la figura del tutor como un deber ejercido en beneficio del tutelado bajo la salvaguardia de la autoridad judicial y la vigilancia del Ministerio Fiscal ${ }^{131}$.

En este sentido, el artículo 269 del Código civil enumera las obligaciones del tutor ${ }^{132}$, generándose una serie de responsabilidades por el inadecuado ejercicio de sus funciones ${ }^{133}$.

${ }^{131}$ Artículo 216.1 C.c.: "Las funciones tutelares constituyen un deber, se ejercerán en beneficio del tutelado y estarán bajo la salvaguarda de la autoridad judicial».

Véase la STS de 5 de marzo de 1947: «... la intervención judicial en materia de tutela reviste un carácter activo, pudiendo ser ejercitada por iniciativa propia sin que en su actuación «ad tuendum» se hallen los Tribunales subordinados necesariamente a la solicitud de parte».

En este sentido, MUÑIZ ESPADA, E.: Las personas jurídico privadas tutoras, Bosch, Barcelona, 1984, p. 32; LETE DEL RÍO, J.M.: ob. cit., p. 32.

${ }^{132}$ Artículo 269 C.c.: "El tutor está obligado a velar por el tutelado y, en particular:

$1^{\circ}$ A procurarle alimentos.

$2^{\circ} \mathrm{A}$ educar al menor y procurarle una formación integral.

$3^{\circ}$ A promover la adquisición o recuperación de la capacidad del tutelado y su mejor inserción en la sociedad.

$4^{\circ} \mathrm{A}$ informar al Juez anualmente sobre la situación del menor o incapacitado y rendirle cuenta anual de su administración».

${ }^{133}$ Para una idea más precisa sobre la responsabilidad del organismo tutelar por el defectuoso cumplimiento de sus obligaciones, véase, YZQUIERDO TOLSADA, M.: 
En correlación con ellas, se regulan también una serie de derechos que vienen reconocidos al mismo. El artículo 220 prevé el derecho del tutor a ser indemnizado a cargo de los bienes del tutelado cuando éste sufra algún daño en el ejercicio de su función ${ }^{134}$. Se afirma de este modo y de manera muy novedosa, la responsabilidad subsidiaria del patrimonio del tutelado, y no necesariamente como consecuencia de los daños sufridos por el tutor por la conducta dañosa de aquél; es decir, habiendo sufrido el tutor, sin culpa por su parte, unos daños en el ejercicio de su función, y no pudiendo obtener su reparación por otro medio, el legislador considera suficiente la concurrencia de tales requisitos para atribuir las consecuencias del hecho dañoso al patrimonio del propio tutelado.

El problema nos lo encontramos en el supuesto de que el tutelado cuente con un patrimonio nulo o insuficiente para hacer frente a la indemnización que el tutor ha de cobrarse como consecuencia de los daños o perjuicios sufridos por desempeño de su cargo. Así el propio precepto 220 añade el requisito de que el patrimonio del tutelado como cauce reparatorio de los daños sufridos por el tutor no debe suponer un deterioro del mismo de modo que conlleve a la desatención de las necesidades básicas del tutelado; es decir, no podemos dejar de desatender las necesidades del tutelado para proteger un interés de menor entidad, como es el derecho del tutor a ser resarcido por los daños sufridos ${ }^{135}$.

A nuestro juicio, en el supuesto en el que el tutor ostente el derecho a ser indemnizado y no pueda serlo, como consecuencia de un patrimonio insuficiente del tutelado, cabría proponer la participación activa de la Administración pública, de modo que se constituya un fondo del que se derive el resarcimiento e indemnización del tutor.

Por su parte, el tutor tiene derecho a una cierta retribución por el ejercicio de su cargo, al igual que el curador y el defensor judicial, siempre y cuando el Juez considere oportuna su fijación (art. 274 C.c.).

Responsabilidad civil y guarda legal, en Documentación jurídica, t. XI, enero/marzo 1984, Madrid, 1984, p. 86.

${ }^{134}$ Artículo 220 C.c.: «La persona que en el ejercicio de una función tutelar sufra daños y perjuicios, sin culpa por su parte, tendrá derecho a la indemnización de éstos con cargo a los bienes del tutelado, de no poder obtener por otro medio su resarcimiento».

${ }^{135}$ YZQUIERDO TOLSADA, M.: ob. cit., p. 83. 
Finalmente, la redacción inicial del artículo 268 reconocía el derecho del tutor a recabar el auxilio de la autoridad, y corregir al menor razonada y moderadamente ${ }^{136}$.

En líneas generales, la doctrina se muestra favorable a las modificaciones operadas por la Ley 13/1983, de 24 de octubre de reforma del Código civil en materia de tutela ${ }^{137}$. La vasta reforma realizada, del Ius familiae es probablemente la materia que menor número de discrepancias ha suscitado; así lo prueba la escasa vivacidad de la discusión parlamentaria y la mínima repercusión de la ley en la opinión pública. Ello se debe con seguridad a que existe un consenso doctrinal generalizado, en el sentido de que el sistema instaurado en 1889 había fracasado radicalmente y era preciso modificarlo en profundidad.

Con posterioridad a la reforma de 24 de octubre de 1983, parte del régimen jurídico de la tutela ha sido reformado por la Ley 21/1987, de 11 de noviembre sobre adopción, y la LO 1/1996, de 15 de enero, sobre protección jurídica de los menores. Aunque los respectivos objetos de estas normas no atañen específicamente a la tutela, han venido a ocuparse de ciertos extremos de ésta, estableciendo como novedades más señaladas la vigilancia del Ministerio Fiscal, y la previsión de una tutela automática por ministerio de la ley para los menores desamparados, por medio de la tutela de acogimiento ${ }^{138}$.

${ }^{136}$ En la actualidad, tras la modificación realizada por la Ley 54/2007, de 28 de diciembre, de Adopción Internacional, el artículo 268 del Código civil determina que «los tutores ejercerán su cargo de acuerdo con la personalidad de sus pupilos, respetando su integridad física y psicológica.

Cuando sea necesario para el ejercicio de la tutela podrán recabar el auxilio de la autoridad».

A nuestro entender, la modificación operada por la Ley anteriormente citada refleja la progresiva supresión de los derechos que desde tiempos antiguos le vienen reconocidos al tutor («Los sujetos a la tutela deben respeto y obediencia al tutor...»), por una serie de deberes («Los tutores ejercerán su cargo de acuerdo con la personalidad de sus pupilos, respetando su integridad física y psicológica...»). Con ello, se pone de manifiesto la evolución experimentada por la institución tutelar pasando de ser una figura objeto de derechos a configurarse como una especie de «officium» siempre al servicio del tutelado.

137 SANCHO REBULLIDA (F.) y LACRUZ BERDEJO (J.L.): La tutela e instituciones afines conforme a la Ley de 24 de octubre de 1983. Apéndice al Derecho de Familia, Barcelona, 1983, pp. 12 y 13.

${ }^{138}$ Artículo 172.3 C.c.: "La guarda asumida a solicitud de los padres o tutores o como función de la tutela por ministerio de la ley, se realizará mediante el acogimiento familiar o ela cogimiento residencial. El acogimiento familiar se realizará por la persona o personas que determine la Entidad Pública. El acogimiento residencial se ejercerá por el Director del centro dónde se ha acogido al menor». Si bien, esta tutela por ministerio de la ley ha de considerarse supletoria debiendo cesar tan pronto como desaparezca la causa que la motivó (RDGRN de 30 mayo 2006). 


\section{H) LA LEY 41/2003, DE 18 DE NOVIEMBRE, DE PROTECCIÓN PATRIMONIAL DE LAS PERSONAS CON DISCAPACIDAD.}

En los tiempos que corren, la extensión de ciertas pandemias, el envejecimiento incesante y creciente de la población, con las colaterales enfermedades (demencia senil, Alzheimer, etc.), provocan la necesidad de que, antes de llegar a la incapacidad de comunicarse y gobernarse, cualquier persona pueda prever la regulación de distintos aspectos de su existencia. Además, el cambio demográfico experimentado por la sociedad estos últimos años ha permitido duplicar la población mundial desde 1960, como consecuencia, fundamentalmente, de la menor mortalidad y del aumento de la esperanza de vida $^{139}$.

Pues bien, vistas las circunstancias que nos rodean y la consecuente necesidad de protección de las personas discapacitadas y de su patrimonio, las Cortes Generales aprobaron la Ley 41/2003, de 18 de noviembre, de protección patrimonial de las personas con discapacidad y de modificación del Código civil, de la Ley de Enjuiciamiento Civil y de la normativa tributaria con esta finalidad.

Esta Ley ha incorporado importantes y novedosas modificaciones en el ámbito del Derecho civil ${ }^{140}$ siendo dos las que merecen una especial mención debido al tema de estudio que nos compete. Por un lado, prevé la posibilidad de que personas que en la actualidad son capaces puedan adoptar precauciones en previsión de una futura incapacitación, mediante dos figuras: la «autotutela», o nombramiento del tutor en un documento público notarial (art. 223, párrafo $2^{\circ}$ C.c.); y los poderes preventivos, es decir, la determinación de la continuación del mandato en el caso de incapacitación judicial sobrevenida del mandante (art. 1.732, párrafo último C.c.). Por ello, el incremento del número de personas que progresivamente van alcanzando una edad más elevada lleva a la inevitable consecuencia de que muchos de ellos vayan perdiendo gradualmente su capacidad de autorregimiento hasta que finalmente resultan incapacitadas. Esta es la cuestión

${ }^{139}$ GUILLÉN, M. (Cada vez vivimos más tiempo y mejor, en «Longevidad y Dependencia», en el Diario ABC de 19 de enero de 2007) apunta como a principios de 2007, la expectativa de vida en España se ha visto incrementada hasta los 74,84 años para los hombres y los 83,51 para las mujeres.

${ }^{140}$ En relación a las aportaciones de la Ley 41/2003, de 18 de noviembre, resulta imprescindible la consulta de la obra colectiva coordinada por Pérez de Vargas Muñoz, (J.) (Protección Jurídica Patrimonial de las personas con discapacidad, La Ley, Madrid, 2006), y en concreto, la aportación de BELLO JANEIRO, (D.) sobre Autotutela e Incapacitación Voluntaria, cit. p. 34. 
que el legislador, con tremenda sensibilidad social, se ha atrevido a ahondar dotándonos, por tanto, de la posibilidad de elegir a nuestro futuro tutor (o curador), rechazar a quienes, por la razón que fuere, no queremos que nunca lleguen a ejercer ninguna función asistencial, así como establecer de antemano los órganos de fiscalización y control de estas personas ${ }^{141}$

Por su parte, esta Ley incorpora a la redacción del artículo 239 del Código civil la posibilidad de que la tutela de la persona incapaz sea asumida por la entidad pública, que a sus efectos, corresponda ${ }^{142}$.

La Disposición adicional primera de la Ley 41/2003, de 18 de noviembre, tiene por rúbrica «Actos de Jurisdicción Voluntaria» y establece que «Las actuaciones judiciales previstas en el capítulo I de esta Ley se tramitarán como actos de jurisdicción voluntaria sin que la oposición que pudiera hacerse a la solicitud promovida transforme en contencioso el expediente». La regulación de la jurisdicción voluntaria en un texto distinto de la ley procesal civil general, por la que se rige la jurisdicción contenciosa, supone una novedad respecto de la tradición legislativa anterior conforme a la cual esta materia formaba parte del contenido de los Códigos procesales de 1855 y $1881^{143}$.

La Ley 41/2003, de 18 de noviembre, pretende otorgar a las personas con discapacidad una protección integral de su persona y patrimonio. Supone un notable avance en la defensa de la persona discapacitada y conlleva una reforma de gran calado en todas las materias.

En suma, una vez recorrido el camino de la protección jurídicopatrimonial del menor e incapacitado a través de los distintos textos legislativos civiles que configuran nuestra tradición jurídica, podemos concluir que, en la actualidad, el principal interés de los mismos se centra en lograr el bienestar del tutelado mediante su representación y la correcta administración de sus bienes, en los actos en que la Ley lo requiera.

${ }^{141}$ Véase PÉREZ DE VARGAS MUÑOZ, J.: La autotutela: una institución a regular por nuestro Código Civil, en R.D.P., diciembre 2001, p. 973.

${ }^{142}$ Artículo $239.3^{\circ}$ C.c.: "La entidad pública a la que, en el respectivo territorio, esté encomendada la tutela de los incapaces cuando ninguna de las personas recogidas en el artículo 234 sea nombrado tutor, asumirá por Ministerio de la Ley la tutela del incapaz o cuando éste se encuentre en situación de desamparo... ».

${ }^{143}$ Vide al respecto FERNÁNDEZ DE BUJÁN, A.: Protección patrimonial de las personas con discapacidad y jurisdicción voluntaria, en La Protección jurídica del discapacitado, II Congreso regional, Tirant lo blanch, Valencia, 2007, p. 191. 


\section{CONCLUSIONES.}

Las instituciones tutelares se han moldeado para suplir, por un lado, la falta de protección del menor que debido a circunstancias especiales se encuentra desamparado y necesita de un sujeto que le cuide y asista, y por otro, para regular la falta de capacidad de determinados sujetos que no son capaces de regir por sí solos ni su persona ni sus bienes.

Estas instituciones tutelares han ido modificándose a lo largo de la historia, todo ello motivado por las diferentes concepciones sociales y el espíritu jurídico de los pueblos en cada momento histórico.

Por lo tanto, la protección de los más débiles constituye en general no sólo un deber en algunos individuos, sino un deber social. La razón fundamental de las figuras tuitivas se encuentra en un deber de asistencia y protección que tiene su origen en la debilidad e imperfección del ser humano. Así bien, proponemos no caer en el error de olvidarse de aquellos sujetos que por sus especiales circunstancias de vulnerabilidad no pueden acceder al goce y ejercicio de sus derechos y necesitan, por ello, de un determinado cuidado y protección tanto de su persona como se sus bienes. Nos reafirmamos, pues, en el artículo 10, apartado primero, de la Constitución Española, a cuyo tenor: "La dignidad de la persona, los derechos inviolables que le son inherentes, el libre desarrollo de la personalidad, el respeto a la Ley y a los derechos de los demás son fundamento del orden político y de la paz social». 